\title{
Thaw in International Law? Rights in Antarctica under the Law of Common Spaces
}

The frozen lands and seas of Antarctica ${ }^{1}$ may soon be the scene of heated international dispute. Discoveries of valuable resources, including $\mathrm{krill}^{2}$ and $\mathrm{oil}^{3}$ offshore and various minerals such as iron

1. This Note defines Antarctica as the region to which the Antarctic Treaty is applicable: the "area south of $60^{\circ}$ South Latitude, including all ice shelves." Antarctic Treaty, Dec. 1, 1959, art. VI, 12 U.S.T. 794, T.I.A.S. No. 4780, 402 U.N.T.S. 71 [hereinafter cited without cross reference as Antarctic Treaty]. Legal rights on the mainland, continental shelf, and "high seas" within this area have posed separate issues of controversy in the past. See, e.g., Note, Natural Resource Jurisdiction on the Antarctic Continental Margin, 11 VA. J. INT'L L. 374 (1971) (legal status of offshore regions). The present Note, however, will argue that the same legal principles are applicable throughout the Antarctic Treaty area. See p. 849 \& note 213 infra.

2. Krill are tiny crustaceans or microplankton that are rich in protein and present in such "enormous quantities" that the Antarctic Ocean is today "the world's largest unexploited source of protein." Sollie, The New Development in the Polar Regions, 9 CoOPERATION \& CONFLICT 75, 77 (1974). Krill can be consumed both by humans and livestock. Potter, The Antarciic: Any Economic Future?, Bull. Atom. Scientists, Dec. 1970, at 94, 99. Both the Russians and the Japanese have already begun to harvest krill in Antarctic waters. Time, Jan. 5, 1976, at 58, 59. Chile, Poland, and West Germany have begun experimental harvesting, and ships from Taiwan have prospected for krill. Interview with $\mathbf{R}$. Tucker Scully, Bureau of Oceans and International Environmental and Scientific Affairs, U.S. Dep't of State (Nov. 7, 1977) (notes on file with Yale Law Journal) [hereinafter cited as Scully Interview]. (Views expressed in this and all other interviews cited in this Note are individual views alone and do not necessarily reflect official policy of the Department of State, other Departments or Offices, or the United States Government.) The Scientific Committee for Antarctic Research (SCAR), see note 129 infra, is now studying the ecological, technological, and legal factors involved in krill harvesting. Report of a Meeting of the SCAR Group of Specialists on Living Resources of the Southern Ocean, 52 SCAR Bull., Jan. 1976, reprinted in 18 PoLAR REC. 103 (1976). See generally 1 SCAR/SCOR Group of Specialists on Living Resources of the Southern Ocean, Biological InvestigaTIONS OF MARINE ANTARCTIC SYSTEMS AND STOcks (BIOMASS) (1977) (multinational scientific study) [hereinafter cited as BIOMASS]; Everson, Antarctic Krill: A Reappraisal of Its Distribution, 18 Polar Rec. 15 (1976).

3. The existence of oil and natural gas reserves was suggested by offshore drilling in 1973. Official estimates of resource values have been cautious. See Minerat. Resources of Antarctica (United States Geological Survey Circular 705, N. Wright \& P. Williams eds. 1974) [hereinafter cited as MiNerAL Resources, with page citation to Antarctic Hearing, infra], reprinted in U.S. Antarctic Policy: U.S. Policy with Respect to Mineral Exploration and Exploitation in the Antarctic: Hearing Before the Subconm. on Oceans and International Environment of the Senate Comm. on Foreign Relations, 94th Cong., 1st Sess. 35, 54 (1975) (economic viability of Antarctic oil and gas limited by logistical problems in recovery: moving ice, deep water) [hearing hereinafter cited as Antarctic Hearing]. Sensational estimates of reserves of 45 billion barrels of oil and 115 trillion cubic feet of natural gas have been "leaked" from an internal United States Geological Survey (U.S.G.S.) report. Hayes, Antarctic Marine Geology and Geophysics, in A Framework for Assessing Environmental Impacts of Possible Antarctic Mineral Development, pt. II, app., at B-1 (D. Elliott ed. 1977) (National Technical Information Service Doc. Nos. PB-262750, PB-26275I) (environmental impact assessment prepared for U.S. Dep't of State) [volume hereinafter cited as ENvironmental Impacts]. All estimates for Antarctica have been described as "untested" and "highly speculative." Interview with Theodore Sellin, Polar 
onshore, ${ }^{4}$ as well as innovative plans to tap Antarctica's other resources," threaten the continent's peaceful status as a zone of "common access" for all the world. As Antarctic resources become increasingly

Affairs Officer, Bureau of Oceans and International Environmental and Scientific Affairs, U.S. Dep't of State (Nov. 7, 1977) (notes on file with Yale Law Journal) [hereinafter cited as Sellin Interview]. Yet scientists concur that oil and gas are Antarctica's "most attractive mineral potential." Antarctic Resources-Report from the Meeting of Experts at the Fridtjof Nansen Foundation at Polhogda, reprinted in Antarctic Hearing, supra note 3, at 68, 70 [hereinafter cited as Nansen Foundation Report, with page citation to Antarctic Hearing]. See also Report of the Group of Experts on Mineral Exploration and Exploitation $\llbracket I I(A)(i)(3)(1977)$ (unpublished report from the Ninth Antarctic Treaty Consultative Party Meeting) (on file with Yale Law Journal) (further hydrocarbon exploration "foreseeable," commercial exploitation a "possibility") [hereinafter cited as Mineral Exploration]. Technological barriers are not insuperable. See, e.g., EnviRonMenTAL IMPACrs, supra at IV-19 to 21 (oil exploration experience in North Sea and Alaska may be applicable, despite Antarctic moving ice); Mineral Exploration, supra đif I(13), II(A)(i)(5), (iii)(23), (vi) (35) (production technologies being actively developed, may include underwater drilling stations and submarine tankers; exploratory drilling could begin by 1982 or 1987).

4. These include: (1) Iron. Thick deposits of iron ore have been discovered with ore concentrations up to $70-80 \%$, ENvIRONMENTAL IMPACTS, supra note 3, at III-4, and it has been estimated that iron ore found in one region of Antarctica alone could satisfy world needs for 200 years at present rates of use, Nansen Foundation Report, supra note 3 , at 69. See also N.X. Times, Dec. 19, 1976, $\$ 1$, at 26, col. 3 (Soviet team finds "mountain of iron"; American party inspects site that may be "one of the most important ore-bearing structures in the world"). (2) Coal. Extensive deposits of coal have been found, though most of the coal is of poor quality. Nansen Foundation Report, supra note 3, at 70 . Antarctic coal beds are comparable, however, to economically viable deposits in southern Africa, Environmental Impacts, supra note 3 , at Summary $\mathrm{x}$, and the coal could be used locally in Antarctica as a source of fuel, Mineral Resources, supra note 3 , at 53. (3) Copper. Deposits of copper have been reported, id. at 49 , occurring in "thin veins" in several locations, ENvironmental Impacts, supra note 3, at III-4. Mining processes for Antarctic copper would be the same as employed elsewhere, id. at V-11 to 15, and although Antarctic copper production is now considered subeconomic, it could become profitable by 1990, id. at VI-1I, VI-19. See also Craddock, Antarctic Geology and Mineral Resources, in id. pt. II, app., at A-7 (occurrences also of molybdenum, gold, silver, nickel, cobalt, platinum, manganese, tin, mica, beryl, quartz crystal, graphite, phosphate); N.Y. Times, Dec. 29, 1976, at 27, col. 1 (U.S. teams search for uranium deposits). Though known mineral deposits are in some cases small, the presence of substantial deposits is considered likely because of Antarctica's former geologic unity with other continents that are rich in minerals. See, e.g., EnvironMenTal IMpacts, supra note 3, at Summary x, III-6. Finding and exploiting these deposits is hindered by ice in places 13,000 feet thick and covering $98 \%$ of the continent. Id. at Summary vii, II-3, III-1. However, less than one percent of land not covered by ice has so far been geologically examined for economic minerals. $I d$. at VIII-1. Despite estimated high costs of onshore mineral development, see, e.g., id. at Summary xii (projected costs ranging from 1.5 to 10 times market return), future exploitation is possible, Mineral Exploration, supra note 3, I $\operatorname{II}(A)(i)(3)$, and will become increasingly attractive with rising world demand, resource shortages, and advances in technology, Craddock, supra at A.7. Valuable manganese nodules on the seabed around Antarctica might also be exploited in the future. MinERAL Resources, supra note 3 , at 50 .

5. Other valuable resource uses of Antarctica either underway or proposed include: (1) Tourism. Tourists "by the hundreds now invade [Antarctica] by ship and sightsee by low-flying planc." N.Y. Times, Oct. 9, 1977, § IV, at 7 , col. 1. It has been alleged that tourists interfere with Antarctic scientific research, see N.Y. Times, April 25, 1971, $\$ 10$ (Travel), at 1 , col. 1 (assistance required from naval station), and pose a threat to Antarctic wildlife, see Summary of Sierra Club Meeting on Environmental Policy Considerations in the Antarctic Region 2 (unpublished paper issued June 15, 1976) (on file with Yale Law Journal) [hereinafter cited as Sierra Club Report]. Consequently, steps have 
desirable, seven states that assert historical rights of sovereignty over sectors of Antarctica ${ }^{6}$ may press their claims more actively. An inner circle of twelve original signatories to the Antarctic Treaty ${ }^{7}$ may also seek to assume exclusive rights of governance and to divide resources among themselves, thus excluding other states from benefits and jeopardizing the common world interest in Antarctic environmental planning. 8

This Note argues that exclusive sovereign rights and beneficial activities in Antarctica are barred by contemporary principles of international law. These principles have evolved through many years of multinational practice and agreement in Antarctica and in response to changing world needs and expectations. Similar principles have become applicable to other spaces with a comparable history and value: the high seas, the deep seabed, and outer space. Like these regions, Antarctica today must be governed by what this Note will term an

been taken to set aside "special reserves" for tourists. See Report of the Eighth Antarctic Treaty Consultative Meeting Rec. VIII-9 \& Annexes A, B, C, in 53 SCAR BuLL., May 1976, reprinted in 18 PolAR REc. 201, 222-23 (1976) (providing for rules of tourist behavior and restrictions on mobility of tourists in Antarctica) [hereinafter cited as Eighth Consultative Report, with page citation to 18 PoLAR REC.]; Report of the Ninth Antarctic Treaty Consultative Meeting $\llbracket \mathrm{I}(16)$ (document to be published in Polar Record, on file with Yale Law Journal) (U.S. seeks to deter "interference by tourists" with sites of scientific interest) [hereinafter cited as Ninth Consultative Report]. (2) Jcebergs. One imaginative proposal is to tow icebergs to dry regions as a source of fresh water, a scheme with enormous potential because $90 \%$ of the world's fresh water is frozen into Antarctica's ice sheet, Mineral Resources, supra note 3 , at 53 , which "calves" at its perimeters to produce icebergs. Saudi Arabian interests have seriously considered towing a 100-million-ton iceberg to the Arabian Peninsula, and proposals have also been made to tow icebergs to Southern California. Trme, Oct. 17, 1977, at 65; N.Y. Times, Nov. 11, 1976, at 40, col. 1 (editorial) (describing Arabian and California plans and raising question of ownership of icebergs). See generally Lundquist, The Iceberg Cometh?: International Law Relating to Antarctic Iceberg Exploitation, 17 NAT. Resources J. 1 (1977). (3) Nuclear waste disposal. More controversially, Antarctica has been proposed as a dumping ground for nuclear wastes because of its thick ice sheet and bedrock beneath. Zeller, Saunders \& Angino, Putting Radioactive Wastes on Ice, Bulc. Atom. Scientists, Jan. 1973, at 4, 9. The radioactive deposits would require "constant surveillance" for 250,000 years. Id. at 5. See also 50 SCAR BuLr., May 1975, reprinted in 17 PoLAR REC. 575, 578 (1975) (ice sheet nuclear waste disposal study of U.S. Atomic Energy Comm'n). But cf. Eighth Consultative Report, supra Rec. VIII-12 at 225 (opposing disposal of nuclear waste in Antarctic Treaty Area). A disposal plan would also require amendment of the Antarctic Treaty. See Antarctic Treaty art. V.

6. The seven states are Britain, New Zealand, Australia, Chile, Argentina, Norway, and France. See pp. 811-12 \& notes 29-35 infra (historical bases for claims).

7. See note 1 supra (Antarctic Treaty citations). The "inner circle" states referred" to are the "Consultative Parties": Treaty Parties with authority to appoint representatives to participate in Consultative meetings. See p. 833 \& notes 139.40 infra. There are at present 13 Consultative Parties, of which 12 are the original signatories to the Antarctic Treaty. These 12 are the seven claimant states cited in note 6 supra, plus the United States, the Soviet Union, Belgium, South Africa, and Japan, see pp. 813-14 \& notes 39-42 infra (programs of nonclaimant states in Antarctica). The thirteenth Consultative Party, Poland, has been a Treaty signatory since 1961 but a Consultative Party only since 1977. See pp. 833-34 \& note 141 infra.

8. See pp. 842-44 \& notes 182-91 infra (proposals for rule of Antarctica by condominium of Consultative Party states). 
international "law of common spaces." The doctrine articulated in this Note provides that no party or exclusive association of parties may exploit nonrenewable resources, create dangers to the environment, or establish any system of exclusive control in spaces that are, or may become, of value to mankind generally and for which there has developed a practice or general expectation of common access, use, or control. Decisions concerning the use or preservation of "common-space" regions and resources may be made only through a process that represents all major interests of the world. Since Antarctica conforms to the definition of a "common space," a fully international regime must be established for Antarctica prior to the commencement of activities that may have irreversible material effects and prior to the implementation of any fundamentally new regulatory scheme.

To demonstrate the applicability of the law of common spaces to Antarctica, the Note will show in Part I that common-space rights are grounded in the history of human exploration of Antarctica. Moreover, the several territorial theories still invoked in support of exclusive claims in Antarctica have never been validly applied and spring from a colonial era long since passed. Part II will argue that the Antarctic Treaty, as well as international practices and expectations that have evolved since the signing of the Treaty, affirm common-space rights and lay no foundation for exclusive schemes of regulation or control. Part III will outline in greater detail the principles of the law of common spaces applicable to Antarctica and will propose steps to be taken to establish a fully international common-space regime.

\section{Evolution of the Antarctic "Common Space": Rebuttal to Existing Territorial Claims}

Seven states today claim rights of sovereignty over sectors of Antarctica or exclusive rights to exploit Antarctica's resources. ${ }^{9}$ These claims, and the possibility that other states active in Antarctica will claim exclusive rights of governance or special rights to resources, ${ }^{10}$ are serious obstacles to the institution in Antarctica of a fully international regime. This Part demonstrates that exclusive territorial claims in Antarctica are untenable for three reasons: the claims violate the historical pattern of international practice and agreement in Antarctica,

9. See note 6 supra.

10. States most likely to join the territorial claimant states in asserting such special rights are the Antarctic Treaty Consultative Parties that have not already asserted exclusive claims: the United States, the Soviet Union, Belgium, South Africa, Japan, and Poland. 
rest on inadequate application of various doctrines of international law, and rely on outmoded assumptions derived from a bygone era of colonialism.

\section{A. Historical Exercise of Common Rights in Antarctica}

It is well established in international law that a customary or historical practice by persons and states may create binding international rights and obligations. ${ }^{11}$ Applying this principle to Antarctica, a long history of cooperative human activity in the region demonstrates the continuous exercise of common rights and undermines the notion that certain states have exclusive rights to Antarctica or its resources.

Rights of free mobility have been exercised by parties of many nationalities throughout Antarctica since the earliest days of exploration..$^{12}$ Early explorers touched base at many points along the Antarctic

11. Customary practice is afforded a central role in international law by the statute establishing the International Court of Justice: "The Court, whose function is to decide [disputes] in accordance with international law ... shall apply [inter alia]: ... (b) international custom, as evidence of a general practice accepted as law . . . ChARter of The United Nations, Statute and Rules of Court, [1947] I.C.J., ser. D, No. I, Statute of the Court art. 38(I). The International Court has applied this principle in many of its decisions. See Fisheries Jurisdiction Case, [1974] I.C.J. 3, 25-26 (principle of preferential fishing rights of coastal states evidenced by "contemporary practice of States"); Case Concerning Right of Passage Over Indian Territory, [1960] I.C.J. 6, 40 (Portugal has Iegal right to cross territory of India to reach colonial enclaves where "constant and uniform practice" had "continued over a period extending beyond a century and a quarter," thereby giving rise to "right and a correlative obligation"); Asylum Case, [1950] I.C.J. 266, 276 (custom legally binding when practiced "in accordance with a constant and uniform usage"); cf. The Scotia, 81 U.S. 170, 187-88 (1871) (British steamer involved in collision found without fault in following navigational rules that were "accepted as obligatory . . . by more than thirty of the principal commercial states of the world" and "acquiesced in as of general obligation ... by common consent of mankind," constituting therefore "the laws of the sea"). The central role of custom has been attributed to the "glaring absence of law-creating agencies" in international society, with "no central court of compulsory jurisdiction" and "no central world legislature." A. D'Amato, The Concept of Custom IN INTERNATIONAL LAw $3(1971)$. Custom may in fact be the only source of law in a case that "[h]istorically ... goes back to a period when, and relates to a region in which, the relations between neighbouring States were not regulated by precisely formulated rules but were governed largely by practice." Case Concerning Right of Passage Over Indian Territory, [1960] I.C.J. 6, 44. See pp. 809-11 \& notes 12-26 infra (early practice in Antarctica). Though treaties are also important instruments of international law, see pp. 82933 \& notes 111-38 infra (Antarctic Treaty), custom may sometimes be "more important" than treaties since custom is "generally regarded as having universal application, whether or not any given state participated in its formation or later 'consented' to it." A. D'AMATo, supra at 4. Cf. L. OPPENHEIM, INTERNATIONAL LAw 25-26 (7th ed. 1948) (treaties interpreted "in case of doubt" according to international custom, because custom is "the older and the original source of International Law"); Tunkin, Co-Existence and International Law, 95 Recuerl. Des Cours 5, 8-23 (1958) (interactive role of custom and treaties). See generally, e.g., Y. BLUM, Historic Tithes in INTERnational LAw 39 (1965) (custom "vital and fundamental factor in the growth and development of . . . [international] law"); C. Parky, The Sources and Evidences of International Law 62 (1965) (custom determined according to "what the generality of States do").

12. See notes 56, 59 \& 60 infra (numerous early explorers in same or overlapping regions). 
coast and later ventured inland on routes that often crossed or led toward common destinations. ${ }^{13}$ Nations sometimes provided important forms of logistical and material support to expeditions of other nationalities. ${ }^{14}$ Frequently, early exploring parties were multinational..$^{15}$ There is little history of efforts by early explorers to hinder the progress of others, and no political authority imposed restrictions of any kind upon their free mobility. ${ }^{16}$

Similarly, whaling and sealing expeditions that circled the outer islands and coastal regions of Antarctica recognized no territorial boundaries to their commercial activities and accepted no national authority to tax, license, or otherwise regulate their trade. ${ }^{17}$ Attempts to discourage excessive marine exploitation have been made instead through international convention, which reflects an understanding of shared rights to Antarctic resources and the common, international interest in resource conservation. ${ }^{18}$

13. See, e.g., Bertram, Antarctic Prospect, 33 INr'L AFf. 143, 147-53 (195') (detailing historical involvement of 12 nations in Antarctica; Norwegian explorer first to arrive at South Pole).

14. See, e.g., The Conference on Antarctica 6-7 (1959) (U.S. Dep't of State Publication No. 7060) (Cape Town, South Africa, was often "port of call" for Antarctic explorers of different nationalities in nineteenth and early twentieth centuries) [hereinafter cited as Conference on ANTARctica]. Similar support among nations has continued in recent years. See, e.g., Auburn, The Ross Dependency-An Undeclared Condominium, AuckLand U.L. REv., Oct. 1970, at 89, 105 (to benefit from U.S. logistical support, New Zealand opens base in 1958 just two miles from U.S. base); N.Y. Times, Jan. 9, 1962, at 19, col. 5 (disabled Australian flown by relay of U.S. and Soviet Union aircraft to New Zealand).

15. See, e.g., Goldie, International Relations in Antarctica, Australian Q., Mar. 1958, at 7, 17 (Australian explorers in British-led expedition in 1907-1909); Mouton, The International Regime of the Polar Regions, 107 RecueIl DEs Cours 169, 180 (1962) (joint Norwegian-British-Swedish expedition in 1949-1952; British-Dutch-Norwegian in 1953 and 1954; British Commonwealth Trans-Antarctic Expedition in 1955-1958; U.S.-New Zealand in 1957).

16. For example, despite letters of protest from Great Britain on behalf of New Zealand, G. HACKWORTH, I Digest OF INT'L LAw 456-57 (1940), the United States in the 1940s conducted extensive explorations in the sector claimed by New Zealand, including a program in 1946-1947 with 13 U.S. ships and 4000 men, Richardson, New Zealand's Claims in the Antarctic, 33 NEw ZeALANd L.J. 38, 41 (1957).

17. See, e.g., Archdale, Claims to the Antarctic, [1958] Y.B. WorLd AFF. 242, 256 (Soviet whaling fleet after 1946); Bertram, supra note 13, at 150 (Norwegian whalers in carly nineteenth century); cf. L. QUartermain, New Zealand aNd THE ANTarcic 60 (1971) (failure of New Zealand's efforts to tax whaling by other nations in claimed sector in 1930s); Mouton, supra note 15, at 221 (Netherlands, Japan, and Soviet Union engage in Antarctic whaling without making territorial claims).

18. The International Whaling Convention, dating from 1931, and the Convention for the Conservation of Antarctic Seals, signed in 1972, sought to regulate harvesting. BIOMASS, supra note 2, at 20; cf. Mouton, supra note 15, at 222-25 (International Whaling Commission established in 1946 to regulate allowable catch by nation, provide ship-board inspectors, publish catch reports). But cf. Dasmann, Conservation in the Antarctic, 3 ANTARCTIC J. U.S. 1, 6 (1968) (Commisssion ineffective in barring whale slaughter). See generally p. 838 \& note 157 infra (many states likely to join in planning new regime to regulate use of Antarctic marine living resources). 
Nations also established bases and stations at locations freely chosen along the coast and later in the Antarctic interior. ${ }^{19}$ These early outposts were highly impermanent; stations established one year would often be abandoned the next, sometimes to be reoccupied by parties of a different nationality. ${ }^{20}$ International activity in Antarctica reached a high point in the International Geophysical Year of 1957-1958 (I.G.Y.), when by international agreement nations cooperated closely in establishing and supplying new stations, exchanging personnel, and sharing information. ${ }^{21}$ States with little or no previous history of Antarctic experience became actively involved, ${ }^{22}$ and states engaged in only peaceful activities. ${ }^{23}$

Today, some stations established in Antarctica have assumed a more permanent character, and stations of the United States, the Soviet Union, and other countries have been placed in many locations across the continent. ${ }^{24}$ Scientists conducting programs of research from these facilities continue to travel freely, and they often cooperate in programs of research with scientists of other nationalities and participate in exchanges of personnel. ${ }^{25}$ Vehicles of supply for these outposts not only cross Antarctica at will, but also at times provide supplies to stations of

19. See, e.g., L. QUARTERMain, supra note 17, at 64-65 (United States establishes its first permanent base in sector claimed by New Zealand).

20. See, e.g., Conference on ANTARctica, supra note 14, at 20 (Norway abandons research station amid negotiations to Iend station to South Africa for use by its scientists); N.Y. Times, Feb. 7, 1959, at 2, col. 7 (Australia assumes custody of United States base).

21. See Mouton, supra note 15, at 181-83, 254-55 (I.G.Y., originally conceived as Third Polar Year, lasted from July 1, 1957 to Dec. 31, 1958; emphasized international amity in Antarctica). See generally P. Jessur \& H. TAubenfeld, Controls for Outer Space and the ANTARctic ANALogy 110-16 (1959); Hanessian, Antarctica: Current National Interests and Legal Realities, [1958] Proc. AM. Soc'y INT'L L. 145, 145-51; Taubenfeld, A Treaty for Antarctica, 531 INT'L Conchlation 245, 265-70 (1961).

22. See, e.g., L. QuaRTERMain, supra note 17, at 77-85 (under impetus of I.G.Y., first active involvement by New Zealand); Hanessian, supra note 21, at 153-54 (first activities since 1899 by Belgium during I.G.Y.; first South African outposts on Antarctic islands).

23. See Mouton, supra note 15 , at 254 (I.G.Y. characterized by "close and happy cooperation" among scientists of many nations); Taubenfeld, supra note 21, at 265 (I.G.Y. "peaceful, cooperative program"). See generally Goldie, supra note 15, at 22-24 (multinational activities in Antarctica during I.G.Y. diminish credibility of national claims).

24. See Antarctica: Stations and Claims (map issued by U.S. Dep't of State) (United States maintains five stations in four different sectors and also at South Pole; Soviet Union maintains seven stations in five sectors; Poland and Japan maintain stations in sectors claimed by other states) (on file with Yale Law Journal) [hereinafter cited as Antarctic Map]. A map showing claimed regions is also available in Antarctic Hearing, supra note 3 , at 15 .

25. See 18 POLAR REc. 379, 379 (1977) (first Italian expedition visits Antarctica in 19751976, establishes base without objection on Antarctic Peninsula-region claimed by three states); Mineral Exploration, supra note 3, I II(A)(iii)(13) (scientists from Japan, New Zealand, and U.S. in joint Dry Valley Drilling Project); note 123 infra (exchanges of scientific personnel through inspections). 
various nationalities at once. ${ }^{26}$ There is no effective understanding that certain regions of the continent are reserved for exploration, settlement, and investigation by parties of particular nationalities; instead, the wide dispersion of settlements and scientific activity demonstrates that the continent in practice is a shared, international territory.

Nevertheless, more than eighty percent of Antarctica remains subject to exclusive claims ${ }^{27}$ issued earlier this century, long after the effective opening of the continent to all the world's explorers. ${ }^{28}$ Despite erratic histories of activity by nationals of each state within claimed regions and, in several cases, equivocal expressions of state interest, territorial claims are maintained today by Britain, ${ }^{29} \mathrm{New}$ Zealand, ${ }^{30}$

26. See, e.g., Ninth Consultative Report, supra note 5, II-Rec. IX-4 (encouraging greater cooperation in transport, including air support coordination).

27. See Antarctic Map, supra note 24 .

28. For dates of formal issuance of these claims and their territorial delimitation, see Note, supra note 1, at $376 \mathrm{n} .13,377 \mathrm{nn} .14$ \& 15 . See generally Antarctic Map, supra note 24.

29. Britain claims to have been the first state to send an explorer (Captain Cook in 1773) into Antarctic waters. ConfERENCE on ANTARCrica, supra note 14, at 34. However, British claims were not formally delineated until 1908. 101 Brit. \& Foreign State Papers 76-77 (1907-1908). Although claiming rights by discovery, Britain claimed lands "whether discovered or not ... comprising more than two-thirds" of Antarctica. Reeves, George $V$ Land, 28 AM. J. INT' L. 117, 117 (1934). (Rights to much of this territory were later "ceded" to New Zealand and Australia. See notes 30 \& 31 infra.) Because of the lack of significant British activity in Antarctica prior to 1908 , no territorial claims since the fifteenth and sixteenth centuries may have been as "badly founded." G. SMEDAL, Acouisition of Sovereignty Over Polar Areas 8-9 (1931). British claims are tenuous also because they overlap with the claims of Argentina and Chile. See note 60 infra; $c f$. Conference on ANTARCTICA, supra note 14, at 34, 37 (British support for "international regime" for Antarctica, preservation of Antarctica for "benefit of mankind in general"); Hayton, Polar Problems and International Law, 52 AM. J. INT'L L. 746, 755 (1958) (British Prime Minister in 1958 calls for full "internationalization" of Antarctica and abandonment of national claims).

30. New Zealand's claims originate in alleged acts of discovery by British explorers and the cession to New Zealand in 1923 of all British "rights" within a claimed sector. 1 G. HACKwORTH, supra note 16, at 458. This sector was mostly unexplored when ceded in 1923, Auburn, supra note 14, at 102, and approximately half of the region is an iceshelf attached only at its perimeter to land, Richardson, supra note 16 , at 40 . This shelf fluctuates in size by season and sections of it periodically break off and float away as icebergs. Auburn, The White Desert, 19 INT'L \& CoMp. L.Q. 229, 247 (1970) [hereinafter cited as Auburn, White Desert]. New Zealand in 1923 purported to apply its laws to the sector, but because there was little human activity to which such laws could apply the government recognized that it held no "accepted authority." Richardson, supra note 16, at 40-42. See also L. QuARTERMaIN, supra note 17, at 60-62 (until establishing Antarctic base in 1957-1958, New Zealand took little interest in Antarctic territory; New Zealand newspaper in 1946 reports that country's claim is "little more than nominal"); Auburn, supra note 14, at 102 (New Zealand's claim is "shaky"). New Zealand's small Antarctic program is fully dependent on logistical support provided by the United States, Auburn, White Desert, supra at 231, 248-50, and the New Zealand government itself makes administrative distinctions between the sector and mainland New Zealand, id. at 250. See also C. BEEBY, ThE ANTARcrtc TreatY 9-10 (1972) (because of New Zealand's weak juridical claim, internationalization may be best guarantee of some positive role in Antarctica for New Zealand); CoNFERENCE ON ANTARCTICA, supra note 14, at 10 (New Zealand proposes to abandon claims if other states do likewise). 


\section{Australia, ${ }^{31}$ Chile, ${ }^{32}$ Argentina, ${ }^{33}$ Norway ${ }^{34}$ and France. ${ }^{35}$ These states claim exclusive sovereign rights to wedge-shaped Antarctic "sectors"}

31. Approximately one-third of Antarctica is claimed by Australia. See Antarctic Map, supra note 24. Although there is some history of earlier Antarctic exploration by Australians, Australia's claims originate in the cession of rights from Britain in 1926. Archdale, supra note 17 , at 250,253 . But see W. SulLIVAN, QUEST fOR A CoNTINENT 123 (1957) (administrative absorption of Antarctic territory by city of Canberra in 1954 was "as though the District of Columbia had been enlarged to include Alaska"); Goldie, supra note 15, at 17-18 (rights gained by Australia only "paper claims," reflecting no ongoing activity by Australians in Antarctica at the time; first Australian station established on Antarctic mainland only in 1954). Yet today Australia, along with Chile and Argentina, is one of the states most adamant in supporting its Antarctic claims. Sellin Interview, supra note 3.

32. There is no substantial record of direct entry by Chileans into Antarctica prior to Chile's delineation of its territorial claim in 1950. Archdale, supra note 17, at 254-55. Along with Argentina, Chile rests its Antarctic claims on arcane theories of uti possidetis, see note 43 infra, and "contiguity," see pp. 815-16 \& notes 44-52 infra. Chile has been adamant about its Antarctic claim, arguing that the territory constitutes part of Chile's "metropolitan territory" and a "southernmost province." CONFERENCE ON ANTARCTICA, supra note 14, at 17. See also Hayton, The "American" Antarctic, 50 AM. J. INT'L L. 583, 585 \& nn.11-13 (1956) (officials speak of "national patrimony" in Chile, special instruction on Chilean rights in Antarctica given in schools).

33. Argentina issued an expansive Antarctic claim in 1925, P. Jessup \& H. TAubenfeld, supra note 21 , at 146 , following a short history of maintaining a meteorological station on an island 400 miles from the Antarctic mainland, Hayton, supra note 32, at 587. Since establishing this station, Argentina has occasionally attempted to appear sovereign in its sector by "establishing bases, stations, refuges, lighthouses, buoys, post offices, and radiotelegraph stations," CONFERENCE on ANTARCTICA, supra note 14, at 31, and by staking claim notices, Bertram, supra note 13, at 147. In Argentina, Antarctic claims have been propagandized with a "dedication verging on fanaticism." Hayton, supra note 32, at 587. See also id. at 588, 590 (all Argentine maps depict the sector as national territory and Argentines emotionally involved in support of claims); N.Y. Times, Feb. 19, 1964, at 3, col. 3 (Feb. 22 declared "Antarctica Day" in Argentina, celebrating "unrenounceable" sovereignty over area claimed).

34. Some history of Norwegian exploration and whaling in Antarctica preceded the Norwegian claim in 1939. Bertram, supra note 13, at 150. However, Norway abandoned the one station it had maintained briefly within her claimed sector in 1958-1960, CoNFERENCE ON ANTARCTICA, supra note 14, at 20, and no new year-round station has been established since that time, Hanevold, The Antarctic Trealy Consultative Meetings-Form and Procedure, 6 CoOperation \& Conflict 183, 186 (1971); Antarctic Map, supra note 24. See Sollie, Arctic and Antarctic-Current Problems in the Polar Regions, 4 Cooperation \& CoNflict 124, 128 (1969) (Norwegian observer notes that Norway's Antarctic claim "has not received general international recognition," and that Norway's interest in international cooperation may be "subject to a test" if it retains its claim).

35. The most tenuous territorial claim in Antarctica may be that of France. The French claim is based on the alleged sighting of a stretch of the Antarctic coast in 1840 by a French explorer. More than 80 years later, in 1924, the French government laid claim to an undefined area, placing it under the "administration" of the French colony of Madagascar, five thousand miles away. Auburn, supra note 14, at 103. The French defined the Antarctic claim only in 1938. I G. HACKWORTH, supra note 16, at 459. See generally id. at 460 (United States in 1939 refuses to recognize French claims since early explorer " did not even land on the coast claimed for France ... nor has any French citizen visited the area ... since [1840]' "). France established its first base on the Antarctic mainland in 1957-1958. France and the Souturrn and ANtarctic Lands 22 (1962) (publication of Embassy of France). The French Antarctic claim has been subject to some international ridicule. See J. DUKERT, THIS Is ANTARCTICA 87 (1965) (by grouping Antarctic territory with several remote island territories, France provided " 100 or so [scientists], 2000 head of wild cattle, numerous elephant seals and more than one million penguins" with "their own budget ... [and] postage stamps"). 
extending from the South Pole north to the coast and the sea. ${ }^{36}$

Publicists of various nations have long disclaimed the legitimacy of these territorial claims under international law, ${ }^{37}$ and no state other than fellow claimant states has extended to them any form of political or diplomatic recognition. ${ }^{38}$ The validity of the claims is also undermined because several states active in Antarctica maintain no exclusive claims of their own. The United States, since the nineteenth century the most active party in Antarctica, ${ }^{39}$ has made no territorial claim, ${ }^{40}$

36. The one exception is the claim of Norway, which extends only along coastal regions. See Antarctic Map, supra note 24. For discussion of "sector theory" used to delimit Antarctic claims, see pp. 822-24 \& notes 86-90 infra. See also note 60 infra (sector claims of Britain, Chile, and Argentina overlap on Antarctic Peninsula, area with great potential for resource development).

37. See, e.g., I C. Hyde, International Law, Chiefly as Interpreted and Applied by THE UnIred STATEs 352 (1945); Daniel, Conflict of Sovereignties in the Antarctic, [1949] Y.B. WordD AFF. 241, 256-57; Hayton, supra note 32, at 610. See also The Antarctic Treaty: Hearings Before the Senate Comm. on Foreign Relations, 86th Cong., 2d Sess. 49 (1960) (statement of P. Jessup) (claims of "dubious validity") [hereinafter cited as Ratification Hearings]; Hargrove, Environmental Problems of Antarctic Resource Management: Legal and Institutional Aspects 14-15 (Je. 15, 1976) (unpublished paper issued at Sierra Club Meeting) (on file with Yale Law Journal) (grounds for claims "flimsy and arbitrary").

38. The degree to which states extend recognition to claims in Antarctica is an important indication of the validity of the claims under international law. See Schwarzenberger, Title to Territory: Response to a Challenge, 51 AM. J. INT'L L. 308, 311 (1957) (recognition, consent, or acquiescence by third states required to perfect title to territory); cf. U.S. Dep't of State Memorandum to Missions Abroad, 39 Dep'r of STATE Bull. 385, 385 (1958) (withholding diplomatic recognition hinders policy objectives of foreign state); Reisman \& Suzuki, Recognition and Social Change in International Law: $A$ Prologue for Decisionmaking, in Toward World Order aNd Human Dignity 403, 406 (W. Reisman \& B. Weston eds. 1976) (any "government" or other "formal status" to be effective requires pattern of acts of recognition and cooperation of parties within a social system). In Antarctica no exclusive claim has received general international recognition; only the claimant countries mutually recognize one another's claims. Sollie, supra note 2, at 84. This has been considered a major weakness in the claims. See, e.g., Goldie, supra note 15, at 19, 21 (Australian claims; calling for "continuous vigilance" and "seizing of opportunities" to gain an "accepted and recognised" title). Recognition by organs of the United Nations would also carry weight, Reisman \& Suzuki, supra at 411, 418-21 (recognition function of Security Council and General Assembly), but to date the United Nations has abstained from taking any position on issues of Antarctic sovereignty.

39. See Gould, Antarctica in World Affairs, 128 Headline Series 3, $47-48$ (1958) (early U.S. Antarctic explorations); Hayton, supra note 29, at 762 (large-scale expeditions in twentieth century). For detailed reviews of the role of the United States in Antarctica, see generally K. Bertrand, AMericans in Antarctica 1775-1948 (1971); U.S. ANTarctic Projects Office, The United States IN THE Antarctic 1820-1960 (1960). Currently the United States maintains between 339 and 368 persons year-round and between 15 and 24 persons on a seasonal basis in Antarctica. See Antarctic Map, supra note 24.

40. It was the position of the United States in 1924 that no territorial claims in Antarctica could be valid because "the discovery of lands unknown to civilization ... does not support a valid claim of sovereignty unless the discovery is followed by an actual settlement of the discovered country." I G. HAckworTh, supra note 16, at 399 (quoting "Prescott Letter" from U.S. Sec'y of State); cf. id. at 459-62 (other official statements reflecting consistent U.S. policy of nonrecognition of territorial claims in Antarctica). For a more recent articulation of United States policy on claims, see Antarctic Hearing, supra note 3, at 14, 17 (statement of Dixy Lee Ray, Ass't Sec'y of State) (U.S. recognizes no Antarctic territorial claims, considers all claims invalid under international law). Although 
nor has the Soviet Union, which since the 1950s has developed an Antarctic program rivaling that of the United States. ${ }^{41}$ The activities of these and other nonclaimant states in Antarctica ${ }^{42}$ contradict the pretensions of exclusivity of the claimant states and affirm the historical pattern of exercise of common rights of mobility, settlement, and use.

\section{B. Misapplication of Territorial Theories in Defense of Claims}

Although longstanding practice and agreement militate against the validity of exclusive national claims to Antarctica and its resources, states have attempted to find support for their claims in a variety of theories of international law. Several of the theories are arcane and cannot be taken seriously today, ${ }^{43}$ but five theories merit attention.

the United States has also "consistently reserved all its basic historic rights in Antarctica," it has never stated clearly what it understands those rights to be and has not made a claim itself. See id. at 18 (Legal Status of Areas South of $60^{\circ}$ South Latitude, memorandum supplied by U.S. Dep't of State). Even if claims of other states were asserted more actively, it is considered unlikely that the United States would ever issue its own claim. Instead, the "United States would probably attempt to protect its interests in some other way." In. terview with Norman Wulf, Legal Adviser to National Science Foundation (Nov. 7, 1977) (notes on file with Yale Law Journal) [hereinafter cited as Wulf Interview]. See also Sollie, supra note 2, at 84-85 (not to advantage of United States and Soviet Union to assert claims, since least valuable region of Antarctica remains unclaimed, or to recognize other claims of other states, thus barring free activity in those regions).

41. Soviet activities in Antarctica were negligible until the 1940s, but have expanded rapidly since the establishment of the first Soviet base in Antarctica in 1956. Auburn, White Desert, supra note 30, at 236-37; Hayton, supra note 29 , at 755 and nn.30 \& 31 . New scientific installations have been established and extensive scientific activities have been carried out by the Soviet Union, as by the United States, without regard to pre-existing territorial claims of other states. See, e.g., N.Y. Times, Apr. 5, 1972, at 8, col. 1; id., June 29, $1975, \S 1$, at 8 , col. 3. Currently the Soviet Union maintains between 202 and 336 persons year-round and between 75 and 135 additional persons on a seasonal basis in Antarctica. See Antarctic Map, supra note 24. Though asserting undefined interests of its own in Antarctica, the Soviet Union has consistently refused to recognize the territorial claims of any states. See Toma, Soviet Attitude Towards the Acquisition of Territorial Sovereignly in the Antarctic, 50 AM. J. INT'L L. 611 (1956); $c f . J$. Kish, ThE Law of INTERnationaL SPACES 72 (1973) (since U.S. and U.S.S.R. have carried out major part of Antarctic exploration, their opposition to Antarctic territorial claims shows failure of those claims under customary international law).

42. These states include South Africa, Japan, and Belgium, all of which sent representatives to the Antarctic Treaty Conference in 1959. For background of each country's interest in Antarctica, see Conference on Antarctica, supra note 14, at 5-9, 14-15, 33. Poland has recently established bases in Antarctica, see Antarctic Map, supra note 24, and in 1977 was recognized as a Treaty Consultative Party, see note 141 infra.

43. For example, under the theory, of uti possidetis, Chile and Argentina claim to be the sole and natural successors to rights to Antarctica acquired by Spain and Portugal through the Papal Bulls of 1493. Daniel, supra note 37, at 262-66. See also Y. BLUM, supra note 11, at 341-42 app. (Roman origins of uti possidetis, application among Latin states); J. Kish, supra note 41 , at 30 (Chile and Argentina cite uti possidetis theory in peace treaty of 1855). Because modern international law does not recognize the authority of fifteenth-century pontiffs to bind nations five centuries later, this theory carries little weight today. See, e.g., L. Bloomfield, The British Honduras-Guatemala Dispute 94 
Each is an unclear and unconvincing foundation for national claims and therefore an unacceptable basis for reversing the historical trend toward affirmation of common rights in Antarctica.

\section{Contiguity Theory}

Chile, Argentina, New Zealand, Australia, and South Africa claim special entitlements because of the relative proximity of their states to Antarctica. ${ }^{44}$ Rights derived from proximity are asserted even though the southernmost tip of Chile, the nearest state to Antarctica, lies more than four hundred miles from the northernmost tip of the Antarctic Peninsula, ${ }^{45}$ and Australia lies two thousand miles from Antarctica. ${ }^{46}$ Although contiguity theory has been cited in other contexts, ${ }^{47}$ its validity as a principle of contemporary international law has been seriously challenged. ${ }^{48}$ Clearly, there is no precedent for the application of contiguity theory from one continent to another, over the great

(1953) (uti possidetis never recognized as an "institution of international law," and binds only "those persons which have ... expressly agreed to it"); Hayton, supra note 32, at 603 (uti possidetis titles withstand "little close scrutiny").

Equally tenuous is the argument that sovereign rights of Latin states in Antarctica are affirmed by the Inter-American Treaty of Reciprocal Assistance ("Rio Treaty") of 1947, through application of the Monroe Doctrine to Antarctica. See Conference on ANTARCtica, supra note 14, at 18 (Chile invokes rights by "Rio Treaty"); Heron, Antarctic Claims, 32 FOREIGN AFF. 661, 666 (1954). This Treaty and other inter-American agreements are only binding on states of the Western Hemisphere in matters of hemispheric self-defense and have never been generally interpreted (except by Chile and Argentina) to create sovereign rights in any state in Antarctica. See, e.g., Daniel, supra note 37, at 263 (Monroe Doctrine pertains to foreign security threats); Mouton, supra note 15, at 245-46, 267-68 (Doctrine never extended to Antarctica, not binding on non-American states; Rio Treaty pertains only to armed attack, and is of no legal consequence in Antarctica).

44. See Conference on ANTARctica, supra note 14, at 17, 26, 31, 49, 51 (theme of proximity cited by representatives of Chile, Australia, Argentina, New Zealand, and South Africa, respectively).

45. See id. at 17 .

46. See id. at 26.

47. Contiguity has been invoked most often in support of mainland control over closely adjacent, unoccupied islands, $1 \mathrm{~J}$. Ferguson, Manual of International Law 100 (1884), or control by government of an occupied island over a surrounding "group of small islands," von der Heydte, Discovery, Symbolic Annexation and Virtual Effectiveness in International Law, 29 AM. J. INT'L L. 448, 468 (1935), as in an archipelago, 1 D. O'Conncl., International Law 484 (1965). Cf. Daniel, supra note 37, at 260 (rights to bordering "frontier" territory); Lauterpacht, Sovereignty over Submarine Areas, [1950] BrIT. Y.B. INT'L L. 376, 430-3I (rights of coastal states over continental shelf). In the Arctic, contiguity theory, described as the doctrine of "region of attraction," has been cited in support of claims of special rights of states adjacent to the Arctic Circle. Lakhtine, Rights Over the Arclic, 24 AM. J. INT'L L. 703, 705 (1930) (Soviet claims). But cf. Kulski, Soviel Comments on International Law, 45 Ax. J. INT'L L. 762, 767 (1951) (Soviet writer resists application of similar concept to Antarctica).

48. See, e.g., The Island of Palmas Arbitral Award (United States v. Netherlands), 2 R. INT'L ARB. AwARDs 829 (1949), reprinted in 22 AM. J. INT'L L. 867, 910 (1928) (contiguity theory "has no foundation in international law") [hereinafter cited as Palmas Island Case, with page references to 22 AM. J. INr'L L.]; Bernhardt, Sovereignty in Antarctica, 5 CaL. W. INT'L L.]. 297, 332 (1975) (contiguity theory "espoused during the nineteenth century" but "now rejected as [a] valid principl[e] in international law"). 
distances separating Antarctica from other lands. ${ }^{49}$ Contiguity theory also has no logical or reasonable application in Antarctica because of the vague and undefined extent of the claims it would support ${ }^{50}$ and because of the potentially huge benefits it would confer for purely fortuitous reasons of geographic location..$^{51}$ Moreover, application of contiguity theory would have a disruptive effect on international relations as other states of the Southern Hemisphere would doubtless join in claiming territories that overlap with lands claimed on different legal grounds by an even greater number of states located far from Antarctica. $^{52}$

\section{Discovery Theory}

European states, with no geographic tie to the Southern Hemisphere but with active histories of exploration, have invoked "discovery"

49. See, e.g., North Sea Continental Shelf Cases, [1969] I.C.J. 4, 30 ("[B]y no stretch of imagination can a point ... situated say a hundred miles, or even much less, from a given coast, be regarded as 'adjacent' . . ..”); I C. HYDE, supra note 37, at 350-51 (contiguity inapplicable across "broad expanses of water" to Antarctica).

50. Because the concept of contiguity sets no geographic limits to its application, it has been criticized as "vague" and capable of "a considerable fluidity of meaning." North Sea Continental Shelf Cases, [1969] I.C.J. 4, 30. See also Palmas Island Case, 22 AM. J. INT'L L. 867,893 (1928) ("principle of contiguity . . . is wholly lacking in precision and would in its application lead to arbitrary results"); Lauterpacht, supra note 47 , at $429-30$ (concept of contiguity "so vague... in its elasticity as to lend itself to abuse in the form of exorbitant and eccentric claims ... . bordering on absurdity").

51. See, e.g., Hayton, supra note 32, at 604 (international community "cannot be presumed" to have "given up to states which are accidentally the closest all rights to unoccupied lands" of value; contiguity "of itself yields no title in the Antarctic or elsewhere"); McDougal, Lasswell, Vlasic \& Smith, The Enjoyment and Acquisition of Resources in Outer Space, 111 U. PA. L. REv. 521, 629 (1963) (proximity alone not logical standard of resource development capacity).

52. See Taubenfeld, supra note 21, at 255 (in today's “divided-up, anti-imperialist world," acquisition of sovereignty through contiguity is "outdated and productive . . . of conflicting claims and potential threats to the peace"). Certainly states located geographically far from Antarctica would protest any scheme that bars them from sharing the benefits of Antarctic resources, just as states without sea borders have insisted on their right to a share of the wealth of deep seabed resources. See Informal Composite Negotiating Text of the Third United Nations Conference on the Law of the Sea, arts. 69, 148, 225, U.N. Doc. A/CONF.62/WP.10 (July 15, 1977) (economic and other rights and interests of land-locked and "geographically disadvantaged" states) [hereinafter cited as Composite Text].

The "hinterland" doctrine, closely allied to contiguity theory, is equally indefensible in application to Antarctica. Under hinterland theory, claims to coastal land are projected inland to encompass territory that is unexplored but that is deemed vital to the "protection" and "subsequent expansion" of the coastal claim. C. Fenwick, INTERNAtionat LAw 348,350 (3d ed. 1948). In Antarctica, the doctrine has been used to justify the extension hundreds of miles to the South Pole of claims originating in tiny settlements along the coast. M. Lindley, The AcQuisition and Government of Backward Territory in InterNATIONAL LAw 4-6, 235 (1926). Stretching the concept of adjacency beyond all reasonable limits, the application of the arcane hinterland concept to Antarctica has been generally repudiated as too prone to cause international disputes, id. at 5-6, "obsolete," Mouton, supra note 15 , at $\mathbf{2 4 5}$, and without "contemporary sanction in international law," Svarlien, The Sector Principle in Law and Practice, 10 PolAR REc. 248, 257 (1960). 
theory in support of Antarctic claims. ${ }^{53}$ These states claim sovereign rights over Antarctic territory that was allegedly first seen, touched, or crossed by explorers from those states. ${ }^{54}$ In accord with ancient custom, some explorers engaged in elaborate, symbolic rituals to reinforce rights claimed by discovery. ${ }^{55}$

Many claims of "first discovery" in Antarctica, however, are disputed. ${ }^{56}$ Confusion arises because many early explorers projected claims over vast regions that they had never seen and that they could not adequately define. ${ }^{57}$ Careful exploration of Antarctica has been conducted only since the mid-twentieth century, many decades after the early discoveries that form the foundation for territorial claims ${ }^{58}$ and often by parties whose nationality differed from that of the original

53. See, e.g., Taubenfeld, supra note 21, at 251 (discovery basis for claims of Australia, Britain, France, and Norway). See also notes 29, 34 \& 35 supra (early explorations and alleged discoveries of Britain, Norway, and France).

54. It is fundamental to "discovery" theory that the "discovered" territory be terra nullius-the "land of nobody"-at the time of discovery. See Advisory Opinion on Western Sahara, [1975] I.C.J. 12, 33 (Sep. opinion of Judge DeCastro) (Western Sahara "must be considered nullius if it was not subjected by legal ties to any State or juridical organization at the time of colonization"). But see Archdale, supra note 17, at 243 (Spain and Portugal, leaders in New World exploration in sixteenth and seventeenth centuries, relied on discovery theory; in nineteenth and twentieth centuries, countries newly active in exploration relied on same theory, discarding their earlier opposition to it); von der Heydte, supra note 47 , at 452 (discovery never fully credible as basis of title, used only when statesmen had "no better arguments to support their political claims").

55. For discussion of early theory and practice of symbolic claims, see A. KELLER, $O$. Lissitzyn \& F. ManN, Creation of Rights of Sovereignty through Symbolic Acts 14001800 (1938); 1 D. O'Connell, supra note 47, at 469 ("symbolic motions" of European Powers). Aiming to satisfy the requirements of this antique theory, "a few men on a sledge" in Antarctica often claimed vast territories either by "flag raising and/or proclamation only," Archdale, supra note 17 , at 243 , or by burying claim documents in the snow, Auburn, Thite Desert, supra note 30, at 234. Since the Antarctic climate made extensive exploration difficult, explorers also devised the modern, expedient technique of claiming "hundreds of thousands of square miles" merely by dropping flags from airplanes. Danicl, supra note 37, at 251. But symbolic devices employed in Antarctica have been subject to international ridicule, see, e.g., W. Sullivan, supra note 31, at 357 (brass plaques, flags, claim sheets, and other emblems now embedded in Antarctic ice as "absurd" vestiges of carly claims of discovery); Daniel, supra note 37, at 25I (symbolic gestures compared to Balboa's "grandiose" claim to Pacific Ocean in 1513), and are of no value in fortifying territorial claims under modern international law, see von der Heydte, supra note 47 , at 461 (contemporary theorists deem symbolic acts "completely incffectual").

56. Conflicting claims of "first discovery" of Antarctica have been made by or on behalf of explorers of Britain, CONFERENCE ON ANTARCTICA, supra note 14, at 34-35; the Soviet Union, id. at 22; and the United States, Gould, supra note 39, at 47-48. Claims of first discovery of particular regions of the continent are also disputed. See note 59 infra.

57. See Auburn, White Desert, supra note 30, at 233-34 (many discoverers had no idea what they were claiming, facts of early discoveries often unclear); Reeves, supra note 29 , at 118 (discovery claims weakened by failure of some explorers even to touch land and by multiple sightings of same coastline).

58. See, e.g., note 35 supra (territorial claim of France not even defined until 84 years after "discovery," no Frenchman set foot on claimed territory for at least first 99 years, no permanent base of exploration established for 117 years). 
discoverer. ${ }^{59}$ As a result, territorial claims founded originally on symbolic acts and discovery rest on questionable historical bases, overlap hopelessly, both with each other and with regions claimed under other legal theories, ${ }^{60}$ and bear little practical relation to subsequent patterns of common access and use.

\section{Effective Occupation Theory}

Some writers have suggested that although discovery alone cannot support a territorial claim in Antarctica, discovery does confer "inchoate title." 61 This inchoate title bars appropriation of territory by other parties for an undefined period after initial discovery, but such title eventually fails unless it is "perfected" through an "effective occupation" of the territory by the claimant state. ${ }^{62}$

A major drawback to effective occupation theory is that the meanings of inchoate title and effective occupation are unclear. International practice has never defined with any precision the period of time that is allowed in order to perfect an inchoate title. ${ }^{63}$ It is also unclear what

59. See Auburn, White Desert, supra note 30, at 234 (various parts of Antarctic Peninsula "discovered" by explorers of at least 10 different nations); cf. Reeves, supra note 29, at 118-19 (discovery claims "open to challenge" because of numerous explorers of different nationality).

60. See Comment, 28 S. CaL. L. Rev. 386, 392 (1955) (any attempt to resolve "innumerable overlapping claims of discovery" in Antarctica would create "appalling . . . conflict as to matters of fact"); cf. Reeves, supra note 29, at 118-19 (explored regions overlap). Already British territorial claims originating in alleged acts of discovery overlap with territory claimed by Chile and Argentina, under contiguity theory, on the possibly mineralrich Antarctic Peninsula. See Antarctic Map, supra note 24; [1956] 1.C.J. PleAdincs, ANTARCTICA CASES (UNITEd KingdoM v. ARGentina; United Kingdom v. ChiLE) (actions brought by Britain before International Court of Justice to resolve dispute, consent to Court's jurisdiction withheld by Chile and Argentina) (Britain arguing rights throughout on basis of various discoveries); P. JEssup \& H. TAubENFELD, suprä note 21, at 148-49 (history of military incidents in the region).

61. See Bernhardt, supra note 48 , at $321-22$ (recent attempt to apply vague inchoate title theory to Antarctic claims). For general explanations of this theory, see $1 \mathrm{D}$. O'CoNNELL, supra note 47, at 478-79; von der Heydte, supra note 47, at 461-62.

62. The doctrine of "effective occupation" or "effective control" has been said to have its genesis following the discovery of America, when Queen Elizabeth of England in 1580 stated that Spain had little valid authority over New World territory since " 'the Spaniards had touched the coast only here and there, had erected shelters, and had given names to a few rivers and capes .... [S] uch insignificant things could in no way entitle them to a property further than in those parts which they actually settled and continued to inhabit':" 2 W. Camden, ANNAles Rerum ANGlicae et Hiberniae 359 (1717), quoted in Daniel, supra note 37, at 249. See also 2 H. Gromus, THE FrEedoM OF THE SEAS 12 (R. Magoffin trans. 1916) (Latin and English texts) ("[T]he act of discovery is sufficient to give a clear title of sovereignty only when it is accompanied by actual possession."); $1 \mathrm{G}$. HACKWORTH, supra note 16, at 399 ("Prescott Letter": United States disputing validity of territorial claims not followed by "actual settlement of the discovered country"). But see Auburn, White Desert, supra note 30 , at $235-36$ (effective occupation rule "if indeed it ever existed, survives only in the textbooks").

63. See Bernhardt, supra note 48 , at 322 (period "varies according to the authority selected"); Hayton, supra note 32 , at 602 (resorting to vague standard of "reasonableness" 
tasks an "occupation" must accomplish to be "effective," and how effective it must be. ${ }^{04}$

A second flaw in occupation theory is the practical difficulty of establishing a significant degree of control or occupation over largely vacant land. ${ }^{05}$ To create the impression of such control in Antarctica, states have engaged in ritualistic behavior-dropping flags from airplanes, ${ }^{60}$ issuing stamps for use in claimed sectors, ${ }^{67}$ appointing regional Antarctic "administrators" and "justices," 88 and staging symbolic tours and visits by home-country heads of state. ${ }^{69}$ But such activity is empty formalism. Symbolic demonstrations have had no human audience over most of the continent and have not deterred travel and settlement by foreign parties within "occupied" territory. ${ }^{70}$ Symbolic displays have been no more effective in supporting claims of occupation than symbolic acts have been in supporting earlier claims of discovery. ${ }^{71}$

to determine grace period). See generally $1 \mathrm{D}$. O'ConNel,, supra note 47 , at 478 (inchoate title involves "mere playing with words"); Goldie, supra note 15, at 12-13 (theory has "always been rigorously criticised").

64. In 1547, "effective occupation" was said to mean the ability "to punish crimes committed within the region in question, and to mete out justice to people coming to that land in order to inhabit it," " ron der Heydte, supra note 47, at 467 (quoting Bartolus, Consilia, Tractatus et Quaestiones 137 (1547)). Since 1547, however, definitions of "effective occupation" have become considerably less precise. Compare Lakhtine, supra note 47 , at 704 ("something in the nature of a permanent settlement, a colonization") with Schwarzenberger, supra note 38, at 316 ("state machinery for purposes of defense and administration"). See generally C. FENwICK, supra note 52, at 346 (standard of occupation has varied from century to century and followed no "definite rule").

65. See J. KiSH, supra note 41, at 53, 73-74 (effective control theory bars national sovereignty where "[n]atural conditions... preclude the feasibility of permanent territorial control," thus precluding national sovereignty in Antarctica).

66. See note 55 supra.

67. See J. DukERT, supra note 35 , at $87-88$. This symbolic device suffered a blow in 1965, however, when Treaty state representatives agreed that no Treaty commemorative postage stamps should be issued showing Antarctica divided by sector claims. Sollie, The Political Experiment in Antarctica, Butc. AToM. Scientists, Dec. 1970, at 16, 20. See also W. Sullivan, supra note 31, at 357 (Antarctic postmasters with "no mail to handle").

68. See W. Sullivan, supra note 31 , at 357 ("Royal Magistrates with no cases to try"); Taubenfeld, supra note 21 , at 252.53 (describing "intermittent ceremonial acts of administration" performed by claimant states to support "tenuous and sometimes conflicting claims" in Antarctica); Note, Quick, Before It Melts: Toward a Resolution of the Jurisdictional Morass in Antarctica, 10 CoRNel. INT'L L.J. 173, 186-87 and nn.60 \& 61 (1976) (claimant states applying domestic laws to sectors in Antarctica).

69. See, e.g., W. Sullivan, supra note 31, at 282 (President of Chile visits Chilean installation in 1948); N.Y. Times, Aug. 11, 1973, at 7, col. 2 (Argentine President and Cabinet visit sector claimed by Argentina).

70. See pp. $810-11$ \& $24-26$ and notes $19 \& 24-26$ supra (nationals of many states traveling and setting up stations in all regions of Antarctica). Technically, the United States station at the South Pole is situated in part within each of the seven claimed sectors. Sullivan, Anlarctica in a Two.Power World, 36 FOREIGN AFF. 154, 154 (1957).

71. See p. 817 \& note 55 supra (symbolic acts of discovery). The inability in practice of symbolic and other acts of administration to exclude other parties from claimed areas suggests that those acts are legally ineffective. See, e.g., J. KIsH, supra note 41, at 52 (territorial sovereignty must involve "ability to exclude all other states from . . [ [sovereign] areas"); Goldie, supra note 15 , at 16 (exclusion of other states necessary, though not suf- 
Stations of scientists and technicians within claimed sectors also have not accomplished their intended purpose of enhancing claims of occupation. ${ }^{72}$ These settlements, even those that remain from year to year, are scientific outposts with small, highly specialized, fluctuating populations. ${ }^{33}$ The stations are fully dependent on imported means of support and are designed to accomplish only limited, scientific tasks. As such, Antarctic stations are less akin to New World colonial settlements of the past than to scientific installations more recently placed on the moon or sent to the bottom of the sea, and they cannot serve as a basis for claims. ${ }^{74}$ Settlements of scientists of many nationalities placed freely within claimed sectors and the mobility of scientists from station to station indicate that any "occupation" of Antarctica is international in fact.

ficient, to establish title); cf. United States v. Alaska, 422 U.S. 184, 200-04 (1975) (Alaska has no "historic title" over Cook Inlet, because foreign vessels and navigation not excluded in practice). Thus, despite exclusive symbolic acts, the numerous expeditions sent by many nations across all sectors show that no part of Antarctica has ever been "at the absolute and undisputed disposition of any state." Bernhardt, supra note 48, at 330-31.

72. States have had overt political objectives in establishing scientific stations in Antarctica. See, e.g., CONFERENCE ON ANTARCTICA, supra note 14, at 18-19 (Chilean representative arguing that "bases ... lend special strength to our claims and rights"); Goldie, supra note 15, at 24 (Australian jurist urging country to establish bases to gain "points of advantage" in order to strengthen Australian claims of sovereignty). The heavy concentration of stations on or just offshore from the Antarctic Peninsula, see Antarctic Map, supra note 24 (15 of 42 total Antarctic stations in 1977), shows the political purposes of these settlements. See Bertram, supra note 13, at 151 (10 British stations maintained in the area for "political reasons"); Gould, supra note 39, at 23 (only political objectives served by having "so many scientific stations so close together"); cf. P. Jessup \& H. TAubenfeld, supra note 21, at 168 (scientific activities in Antarctica not apolitical despite disclaimers of scientists).

73. Nearly one-fifth ( 8 of 42) of Antarctic stations are staffed only in the summer. Antarctic Map, supra note 24. Populations of even the most "permanent" stations are highly transient, thereby diminishing the strength of claims based on effective occupation. See, e.g., Daniel, supra note 37 , at 256-57 (no sovereignty possible in Antarctica, where "normal life is everywhere impossible" and winter lodgers arc "virtual prisoners in ... specially-constructed shelters"); [1958] Proc. AM. Soc'x INT'L L. 166, 167 (commentary by A. Niedle, attorney in Legal Adviser's Office, U.S. Dep't of State) (lack of permanent settlers and rotation of occupants of stations in Antarctica casts doubt upon effectiveness of occupation).

74. For outer space analogy, see Trcaty on Principles Governing the Activities of States in the Exploration and Use of Outer Space, Including the Moon and Other Celestial Bodies, Jan. 27, 1967, art. II, 18 U.S.T. 2410, T.I.A.S. No. 6347, 610 U.N.T.S. 205 (outer space "not subject to national appropriation by claim of sovereignty" or "by means of use or occupation") [hereinafter cited as Outer Space Treaty]; Ratification Hearings, supra note 37, at 70 (H. Phleger, representing U.S. Dep't of State) (claims in Antarctica no more tenable than hypothetical moon claims based on landings). For deep sea analogy, see Composite Text, supra note 52, art. $147(2)(v)$ (seabed installations not to "affect territorial or jurisdictional limits of any kind"); J. KISH, supra note 4I, at 64 (national jurisdiction over seabed stations limited to period of operation, no basis for national claims). See generally pp. 846.48 \& notes 201-11 infra (human experience in outer space and oceans analogous to that in Antarctica, legal doctrines similar). 


\section{Minimal Control Theory}

Faced with the impossibility of demonstrating effective control in Antarctica, claimant states have fallen back on a variant theory: that less control is required to sustain a territorial claim in uninhabited or sparsely inhabited regions than in more heavily populated regions. ${ }^{7 \overline{5}}$ Although finding authority in a series of international cases and arbitral decisions-Eastern Greenland, ${ }^{76}$ Clipperton Island, ${ }^{77}$ Minquiers and Ecrehos, ${ }^{78}$ and Palmas Island ${ }^{79}$-this theory of "minimal control" is no more lucid than its parent concept. The new standard fails to specify what kind of control is required to establish valid title and how "minimal" such control may be. ${ }^{80}$ Under such an ambiguous standard, serious disputes can arise as states rush to capitalize on their "minimal control" of valuable spaces by issuing sweeping, overlapping claims. ${ }^{81}$ In Antarctica such claims have already been made, and the potential for conflict and confusion would increase if a modern attempt were made to apply the ill-defined doctrine of minimal con-

75. See, e.g., M. LInplex, supra note 52, at 158 (in uninhabited lands, "any organization (however rudimentary) . . . sufficient to maintain order" renders occupation effective); Hyde, Acquisilion of Souereignty over Polar Areas, 19 Iown L. Rev. 286, 288 (1934) (in polar areas "facilities of transportation by air" alone may "effectively establish . . . supremacy"); cf. Johnson, Consolidation as a Root of Title in International Law, [1955] Cамв. L.J. 215, 224-25 (proposing sliding scale: lesser degree of "manifestation" of title required in case of competing claims than where title uncontested).

76. Legal Status of Eastern Greenland, [1933] P.C.I.J. 22, ser. A/B, No. 53 (Denmark held to have valid territorial rights to all of Greenland because of peaceful and continuous display of state authority over Greenland; claims to sovereignty over thinly populated or unsettled countries require a lesser showing of sovereign exercise). See generally 0 . Svarlen, The Eastern Greenland Case in Historical Perspective 57-58 (1964) (explication of minimal control principle).

77. Clipperton Island Arbitral Award (France v. Mexico), Jan. 28, 1931, reprinted in 26 Am. J. INT'L L. 390 (1932) (France has superior claim of right to tiny Pacific island because of French discovery and sovereignty claim in 1858 and "effective occupation" thereafter, despite lack of exercise of French authority "in a positive manner"; both French and Mexican claims adjudged "weak").

78. Minquiers and Ecrehos, [1953] 1.C.J. 47 (England v. France) (England has valid title to small group of islands off coast of Normandy because of greater role in process of slow evolution of sovereign control since 933 A.D.). See generally A. ROCHE, THE MINQUIERS AND Ecrehos Case (1959).

79. See Palmas Island Case, 22 AM. J. INT'L L. 867 (1928) (Netherlands holds superior claim because of more convincing demonstration of external signs of sovereignty on island).

80. See, e.g., Auburn, supra note 14, at 91-92 ("ill-defined minimum" standard opens door to new, symbolic "battles of etiquette" by claimant states); Daniel, supra note 37 , at 252 (theory has "such elasticity that most of its fundamentals are absent"). The leading cases on minimal control have also been criticized as throwing only "further darkness" on requirements of occupation. Auburn, White Desert, supra note 30 , at 232. Cf. Hyde, supra note 75, at 287 (minimal control theory represents "recrudescence of ideas and tests" of sixteenth century, founding rights of sovereignty upon "barest formalities").

81. See Taubenfeld, supra note 21 , at 252 (minimal occupation theory may not "provide a politically smooth pattern of partition for any area in which conflicting claims are pressed, as ... in the Antarctic"). 
trol to apportion exclusive territorial rights among the many states now active in Antarctica. ${ }^{82}$

More fundamentally, the circumstances underlying the minimal control decisions make them inapposite to Antarctica. With the exception of the Eastern Greenland case, all of the decisions pertain to tiny islands of negligible importance..$^{\$ 3}$ None of the cases involves world-wide interests in vital resources or environmental planning. ${ }^{84}$ The cases are also distinguishable since no international practice of common rights and access had developed on any of the territories, and none of the lands had been subject (as Antarctica has been since 1959) to a multinational treaty affirming principles of common right. ${ }^{85}$

\section{Sector Theory}

Finally, a "sector" theory has been adapted from its application in the Arctic to support territorial claims in Antarctica. ${ }^{86}$ Under sector theory, Antarctic territorial boundaries are defined according to lines

82. See Antarctic Map, supra note 24 (12 states with stations in Antarctica, stations of nonclaimant states substantially larger than those of claimant states, stations of nonclaimant states widely scattered through claimed sectors); $c f$. Goldie, supra note 15, at 20-21 (doctrines of occupation generally "condon[e] the 'grab and squat' tactics of a gold rush," thus posing dangers to international relations).

83. See, e.g., 1 D. O'CoNNELL, supra note 47, at 474 (Minquiers and Ecrehos case concerned "islands, certain of them habitable, others merely rocks"); Bernhardt, supra note 48, at 330-31 (principles of Clipperton Island case not applicable to an entire continent, such as Antarctica); Lauterpacht, supra note 47, at 428 (Palmas Island award "related only to islands").

84. See, e.g., Clipperton Island Arbitral Award, 26 AM. J. INr'L L. 390, 391-92 (I932) (tiny island of resource interest only to guano collectors).

85. See pp. 829-33 \& notes 111-38 infra (Antarctic Treaty affirming common rights and interests). Any international interest in the contested islands also could not have received a fair hearing, since nation states were competing with each other for title and the arbiter in each case was bound to award title to only one state. See, e.g., Palmas Island Case, 22 AM. J. INT'L L. 867, 911 (1928) ("only one of two conflicting interests is to prevail"); Auburn, supra note 14, at 91 (axbitrator in Clipperton Island case "bound by the terms of the compromise" to confer title on a claimant party, even though "both claims were weak"); cf. Daniel, supra note 37, at 255 (Eastern Greenland decision would not have applied to other states active in Greenland; decision of minimal precedential value for Antarctica); Skagestad \& Traavik, New Problems-Old Solutions, 9 Cooperation \& Conflict 91, 92 (1974) (Eastern Greenland case not dispositive of "political and legal problems of regulation" in "new territories," including Antarctica).

86. The sector theory had its genesis in Arctic claims of Russia and Canada. See T. Taracouzio, Soviets in THE ARctic 320-21 (1938) (Soviets in 1926 adopt principle devised by Canadian senator in 1907); Lakhtine, supra note 47 , at 706.09 (islands and archipelagos claimed by both countries). However, the great distance separating Antarctica from claimant states undermines whatever practical foundation the sector approach may have in the Arctic, where several states that have recognized boundaries extending into or approaching the Arctic Circle have a direct strategic and environmental interest in events in the Arctic. See, e.g., National Legislation and Treaties Relating to the Law of the SEA 183 (United Nations Legislative Series 1974) (Canadian Arctic Waters Pollution Prevention Act of 1970); of. 1 C. HYDE, supra note 37, at 351 (application of Arctic sector theory to Antarctica merely "convenient" and "arbitrary"). 
of longitude converging on the South Pole from either of two types of baselines: mainland boundaries of the claimant state, or a length of the Antarctic coast "discovered" or "occupied" by the claimant state. Both baseline approaches, however, have been haphazardly applied in Antarctica ${ }^{87}$ and have brought about incongruous and divisive boundary results. ${ }^{88}$ Furthermore, the two approaches are theoretically incompatible, since either one applied to its full extent would lead to an apportionment of the entire continent, and logical application of both would produce two distinct and competing sets of claimants. ${ }^{88}$ Thus it is not surprising that the application of sector theory to Antarctica has been widely repudiated.90

More important, "sector theory" is not a theory at all, but merely a convenient manner of delimiting claims founded on other theories. Without contiguity theory, states of the Southern Hemisphere that have no other grounds for claims cannot credibly extend sector lines from their homelands to Antarctica. Similarly, without discovery and occupation theories, Northern states cannot establish the Antarctic coastal rights needed as a base from which to draw their sector lines. By stripping away false sector theory, the frailties of each of the underlying theories are exposed, because no practical or legal means has

87. Only claimant states lying directly across an ocean from Antarctica (Argentina, Chile, Australia, and New Zealand) can delimit sectors by drawing lines of the first type, from mainland boundaries. But most of the territory claimed by Australia, for example, does not lie directly south of Australia but is south of the Indian Ocean. See Daniel, supra note 37 , at $259-60$ (sector lines bear only rudimentary relation to location of claimant states, are "confusing" and a source of conflict). Britain and France, separated by intervening lands and continents from Antarctica, must employ the second type of sector delimitation, using lands claimed along the Antarctic coast as sector baselines. But in practice these baselines have been chosen "rather arbitrarily" and have "only a tenuous connection" with coastal areas actually explored. Taubenfeld, supra note 2i, at 254. Also, to establish the British and French sectors, claims are projected not only inland to the Pole but "backwards at great distances out over the high seas, like a net ... to 'catch' as many islands as possible," an "innovation" of dubious "propriety" under international law. Hayton, supra note 32, at 605; cf. Sollie, supra note 34, at 132 (objecting to purported annexation of "[e]normous stretches of the southern seas" by sector claimants). Only Norway asserts clear rights to just the Antarctic coastline. See Antarctic Map, supra note 24.

88. Some areas of Antarctica remain unclaimed, while other areas are claimed by as many as three states. See Antarctic Map, supra note 24; note 60 supra (three states claim Antarctic Peninsula). Also, the vast Australian claim is bifurcated by the narrow sector claimed by France. Antarctic Map, supra note 24.

89. See, e.g., Comment, supra note 60 , at 397 (variations of sector theory would support "extravagant" claims in Antarctica).

90. Polar sector theory has been repudiated generally, see, e.g., Bernhardt, supra note 48 , at 338 (sector not a valid principle of international law); Hayton, supra note 32, at 605-06 (sector lines arbitrary, "legally irrelevant"), and also specifically with regard to Antarctica, see, e.g., Auburn, supra note 14, at 95 (sector theory applied in Antarctica lacks "any support in law, derives little from logic"); Mouton, supra note 15, at 255 (sector theory "by no stretch of the imagination" applicable to Antarctica). 
been proposed to establish territorial boundaries in Antarctica on the basis of these theories alone. Without sectors, therefore, claimant states enjoy no defense under international law to the continued exercise of common rights by all members of the world community throughout Antarctica.

\section{Changed World Needs and Conditions}

Exclusive claims to territory and resources in Antarctica, besides contradicting historical practice and misapplying territorial theory, are invalid also because they fail to reflect contemporary world needs and conditions. These changed conditions include the demands of a greatly expanded world community, economic interdependence and need, environmental deterioration, and strengthened institutions for international decisionmaking.

Before the mid-twentieth century, Western principles of international law were centrally influenced by European colonial expansion. European states building empires in the Americas, Asia, and Africa justified their foreign programs with the same theories of proximity, discovery, and occupation forwarded by Antarctic claimant states today. ${ }^{91}$ Yet the world political community has changed radically since territorial rights were first claimed in Antarctica. Scores of newly independent states, ${ }^{92}$ most of them poor $^{93}$ and acutely sensitive to

91. The proximity concept with the clearest colonial origins is "hinterland." See C. FeNwICK, supra note 52, at 350-51 (origins in African partition); note 52 supra (application to Antarctica). See also Bernhardt, supra note 48 , at $339-40$ ("contiguity" itself a colonial concept). The concept of res nullius ("property of nobody"), which is fundamental to discovery theory, see note $\mathbf{5 4}$ supra, was applied even to populated lands in the colonial era. See C. Fenwick, supra note 52, at 345 (under res nullius, "wandering tribes" and even "settled peoples" with level of civilization "below the European standard" had no recognized prior rights of occupancy). Also occupation theory was cited to justify European colonial claims. C. Fenwick, supra note 52, at 344; G. SMEdal, supra note 29, at 18. European representatives meeting in Berlin in 1885 formalized many of these principles to aid partition of Africa. C. FenwICK, supra note 52, at 349 . It has been charged that 15 states acting as "quasi-world-legislators" at Berlin "laid down rules . . for the grab of Africa," leading to an "unnatural division" of the continent with enduring consequences. R. ANANd, NEw States and Internatronar. LAw 21, 33 (1972). See generally id. at 45 (international law during colonial era served "the rich, industrial, and powerful states of Western Europe and the United States"); id. at 114 (many concepts of international law "legacy of the age of colonialism and imperialism").

92. See $\mathrm{R}$. ANAND, supra note 91 , at 24 (in 1899, only 26 states involved in international conference); [1959] U.N.Y.B. app. 1, at 539-40 (82 members of the United Nations as of Dec. 31, 1959); 241 Permanent Missions to the United Nations 3-4 (Aug. 1977 ) (142 United Nations members in Aug. 1977).

93. See, e.g., Declaration on the Establishment of a New International Economic Order, United Nations G.A. Res. 320I, S-6 U.N. GAOR, Supp. (No. 1) 3, If 1, U.N. Doc. A/9559 (1974) (benefits of technological progress not shared equitably, $70 \%$ of world's population accounts for $30 \%$ of income) [hereinafter cited as New Economic Order]; R. ANAND, supra note 91, at 46 (new majority of states "small, weak, poor, underdeveloped, former colonies"). 
economic and political control by the major powers, ${ }^{94}$ represent a new political force that has disrupted the "closed club" of an earlier, smaller international society. ${ }^{95}$

Many of these new states have repudiated the doctrines used in building the empires from which they wrested independence, and they have strongly influenced recent evolution of international law. ${ }^{96}$ Among the new legal concepts to emerge are the illegitimacy of colonial control, ${ }^{97}$ obligations of equitable sharing of wealth and resources, ${ }^{98}$ and the right to participate in making decisions of international concern ${ }^{09}$-concepts that challenge the current alignment of power in Antarctica. As Antarctic resources become the subject of

94. See, e.g., New Economic Order, supra note 93, If I (international system, established before independence of developing states, "perpetuates inequality"); Roy, Is the Law of Responsibility of States for Injuries to Aliens a Part of Universal International Law?, 55 AM. J. INT'L L. 863, 881 (1961) (in colonial era " $[t]$ he so-called international community, the smaller but more powerful part, dominated the bigger but weaker part"). These conditions of inequality have been described as leaving the former colonies "filled with resentment" against the colonial powers and "needing and demanding the protection of the international society." $R$. ANAND, supra note 91 , at 46 .

95. R. ANAND, supra note 91 , at 67 (international society no longer maintainable as "closed club").

96. Colonial upheaval had inevitable legal effects. See, e.g., Abi-Saab, The Newly Independent States and the Rules of International Law: An Outline, 8 How. L.J. 95, 97.98 (1962) (independence of African and Asian states to affect all aspects of international law); Roy, supra note 94, at 882 ("new set of laws" needed to govern "new-born world community").

97. This concept is often expressed as the principle of self-determination of peoples. See U.N. ChARTER arts. 1(2), 55, 56, 73(b), $76(\mathrm{~b})$ (affirming principles of self-determination and self-government); Declaration on Principles of International Law concerning Friendly Relations and Co-operation among States in accordance with the Charter of the United Nations, G.A. Res. 2625, 25 U.N. GAOR, Supp. (No. 28) 121, U.N. Doc. A/8028 (1970) (promoting, inter alia, "self-determination of peoples" and "a speedy end to colonialism"). The International Court of Justice has stated that this principle of self-determination is applicable to all "non-self-governing territories." See Legal Consequences for States of the Continued Presence of South Africa in Namibia (South West Africa) Notwithstanding Security Council Resolution 276 (1970), [1971] I.C.J. 16, 31. As a doctrine of anticolonialism, "self-determination" is casily extended as a basis of opposition to colonial schemes even in uninhabited regions such as Antarctica. See Hayton, supra note 32, at 608 ("Colonialism in any form-even over uninhabited lands-is in great disrepute" because "[s]elf-determination" and "equality" are now preferred values; since Antarctica lies within the underdeveloped region, "no major Power can for long thwart the nationalistic ambitions of ... new . . . states" toward Antarctica); cf. P. Jessup \& H. TAubenfend, supra note 21, at 176-77 (though Antarctica has no indigenous population, sector divisions could be "denounced as .... 'imperialist" ").

98. See New Economic Order, supra note 93, II 4(i)-(p) (principles of economic assistance and preferential treatment on equitable basis for developing countries); note 250 infra (special rights of developing countries recognized in current law of the sea text); $c f$. R. ANAND, supra note 91, at 101 (proposing a "legal duty" to promote "social welfare at the international level"); Abi-Saab, supra note 96 , at 119 (international law must "redress the balance of centuries of domination and exploitation by ... big powers of the newly independent states").

99. See New Economic Order, supra note 93, If 2 (calling for "active, full and equal participation of the developing countries in the formulation and application of all decisions that concern the international community"). 
strict world scrutiny, narrow forms of decisionmaking are certain to be challenged by new states seeking a greater role in world affairs, ${ }^{100}$ and doctrinal fictions of exclusive right are likely to give way to more contemporary principles of sharing and common right.

Evolution in legal doctrine brought about by political change has been reinforced by new economic and social conditions. The first of these conditions is that new frontiers of land on earth have diminished, leaving the world's growing populations with few new spaces to settle and use. Colonial theories of discovery and occupation provide little guidance in resolving the critical questions that arise when so little land remains to be apportioned among so many people. Instead, food and resource shortages have led to demands for increased economic aid to the disadvantaged and for wider distributions of wealth, ${ }^{101}$ and attempts to extend exclusive forms of authority into the remaining new frontiers-for instance, the deep seabed and outer spacehave been firmly rebuffed. ${ }^{102}$

In recent years world economic relations have also become more closely integrated. Consequently, the economic fortunes and misfortunes of each sector of the world economy are now matters of universal concern..$^{103}$ Claims of exclusive right to scarce new land and resources, and schemes by developed states to exploit new spaces without benefit to the poor majority, may widen the world's income gap and threaten the vitality of the international economic system itself. ${ }^{104}$ Thus exclusive claims in Antarctica are not only founded on outmoded

100. Even in $\mathbf{1 9 5 9}$ it was noted that partition of Antarctica would arouse wide opposition because the "interests of the rest of the world . . . would have been ignored." $P$. Jessup \& H. Taubenfeld, supra note 21, at 176-77. See also Hambro, Some Notes on the Future of the Antarctic Treaty Collaboration, 68 AM. I. INT'L L. 217, 225 (1974) (anticipating increased pressures from "outside states" for fully international solution); Note, supra note 1, at 404 (international control over offshore regions of Antarctica is in accord with "demand of the developing nations for a share of the promised resource wealth").

101. See note 98 supra.

102. See notes 204 \& 214 infra (international declarations barring national sovereignty over seas and outer space).

103. See, e.g., R. ANAND, supra note 91, at 2 (complex economic life involves "worldwide interdependence"); McDougal, Law and Power, 46 AM. J. INT'L L. 102, 109 (1952) (interdependence "makes any conception of 'national interest,' apart from the interest of most of the peoples of the world, the sheerest of illusions").

104. Economic interdependence creates a need for coordination in world economic planning. See New Economic Order, supra note 93, $\{3$ (since world community is interdependent and interests of developed and developing countries are inseparable, "the prosperity of the international community as a whole depends upon the prosperity of its constituent parts'); Composite Text, supra note 52, art. 150(1)(g) (establishing procedures to protect economies of developing countries from lowered resource prices and other adverse economic effects of seabed mineral exploitation); $c f$. N. Hill, CLAIMS To TERRITORY IN INTERnational LAw AND Relatons 92-114 (1945) (historical precedent for claims to title premised on economic need). 
legal doctrine, but also are ill-advised in light of the world's changing political and economic realities.

A universal interest in the disposition of new lands and resources also arises from mutual concern for the world's environment. The recognition that pollution of land, water, and air are issues of international concern ${ }^{105}$ is pertinent to Antarctica, a vast continent at the hub of important wind and ocean currents ${ }^{106}$ and a region of great aesthetic value ${ }^{107}$ and scientific interest. ${ }^{108}$ The certain marring and possible destruction of these qualities in the course of Antarctic resource development ${ }^{109}$ would constitute a serious loss to, and could directly affect, the entire world community.

105. See Programme of Action on the Establishment of a New International Economic Order, G... Res. 3202, S.6 U.N. G.AOR, Supp. (No. 1) 5, fI I(2)(d), U.N. Doc. A/9559 (1974) (calling for efforts to "refrain from damaging or deteriorating [world] natural resources and food resources ... by preventing pollution"); Declaration of the United Nations Conference on the Human Environment $f$ II(16) (issued by the Stockholm Conference of 1972 , convened by the United Nations General Assembly), reprinted in $1 \mathrm{~B}$. Ruster \& B. Simma, International. Protection of the Environment 118 (1975) ("States have... the responsibility to ensure that activities within their jurisdictions or control do not cause damage to the environment of other States or of areas beyond the limits of national jurisdiction.") See also Skagestad \& Traavik, supra note 85, at 94 ("'new' and 'old' territories constitute an environmental whole, with essential . . . interrelations"; therefore, "[o]ne cannot ... remain indifferent to possible radical changes in the environment of the new territories," including Antarctica).

106. See Ratification Hearings, supra note 37, at 99 (letter from professors of law: Howard Taubenfeld, Stefan Riesenfeld, Jerome Cohen, Lawrence Ebb, Martin Travis) (Antarctica "of interest to all nations" as "source of much of the world's weather"); Environmental Impacts, supra note 3, at Summary xiii-xiv (pollutants in Southern Ocean would be spread worldwide through contact with other ocean currents).

107. See, e.g., Bauer, Tourism Comes to Antarctica, OcEANs, Jan.-Feb. 1974, at 13, 13 ("most awesome scenery in the world"); N.Y. Times, Mar. 11, 1973, § 10 (Travel), at 21, col. 3 (J. Cousteau, describing " "beauty of the landscape, the sea" ").

108. Scientific research is the major activity carried on in Antarctica today. Frazier, $A$ Continent for Science: Research in Antarctica, 105 Scr. News 43, 45 (1974). The continent is highly valued as a laboratory for scientific rescarch. See, e.g., Frazier, The First Probes Beneath Antarctica, 105 Sar. News 60, 61 (1974) (studying the chemical, biological, and ecological characteristics of Antarctic glacier-fed lakes); Purrett, Antarctic Leg: Drilling Among the Icebergs, 102 ScI. News 426, 426 (1972) (investigating ancient history of Antarctic continental drift).

109. Offshore oil development poses the most serious environmental risks. High waves, icebergs, and sudden storms endanger oil tankers in Antarctic waters, ENvironmenTaL ImPACTs, supra note 3, at VII-27 to 28 , and increase the risk of oil spills and blowouts at rigs, id. at Summary xvi-xviii. No methods are currently available to contain or recover oil spilled at sea in Antarctica, Mineral Exploration, supra note 3, II I(21), II(C)(iii)(58), and particularly disastrous environmental consequences are anticipated if such an accident should occur before the onset of the Antarctic winter, ENvironmental IMPACTs, supra note 3, at VII-26. See also Parker, The Case for Conservation in Antarctica, in Frozen Future: A Prophetic Report from ANTARctica 401, 404-05 (R. Lewis \& P. Smith eds. 1973) (oil slick could unbalance local ecosystem for more than century) [volume hercinafter cited as FROzEN FUTURE]. Marine life is most directly threatened by oil drilling at sea. See ENvironmental ImPACTs, supra note 3, at VII-5 (krill swarms endangered); id. at Summary xiv (sea mammals could lose food source, perish through loss of body insulation from oil coating). Also on shore, serious environmental injury may be expected from 
It is not the case today, as it may have been in early days of Antarctic exploration, that no alternative exists to narrow forms of regulation and control. Numerous international institutions now give voice to diverse global interests and allow wide participation in many areas of international activity. ${ }^{110} \mathrm{New}$ machinery of international lawmaking and law enforcement is well suited to cope with issues of common urgency and need in Antarctica. Unilateral seizure of control, and even multilateral accords and regulations (as under the Antarctic Treaty), do not meet the standards of universal participation set by new institutions and cannot fully guarantee in Antarctica the protection of long-exercised common rights.

\section{Ups and Downs of the Antarctic Treaty as a Source of Common-Space Law}

As demonstrated in Part $\mathrm{I}$, theories of territorial acquisition deriving from international law of the colonial era are inapplicable to Antarctica; the historical pattern of practice and agreement indicates that territorial and resource rights in Antarctica must be governed instead by concepts based on worldwide common rights. The Antarctic Treaty of 1959 affirms the applicability of concepts of common rights to Antarctica but fails to establish an appropriate structure for the protection and implementation of those rights. Thus Treaty-based proposals for the administration of Antarctic resources are inconsistent with the principles established by practice and implicit within the Treaty itself.

mineral exploration, see id. at Summary xv (rock drilling), and from exploitation, id. at Summary xvi (terrain modification, discharge of tailings, chemicals, and particulates). Serious and possibly irreversible damage is anticipated to the earth, see id. at VII-1 (unique Antarctic soils developed over millenia to be destroyed by surface construction); the atmosphere, see id. at VII-s (particulates emitted from mining could alter snowfall patterns and rate of ice melting); and biological ecosystems, see ENVIRoNmENTAL Impacts, supra note 3 , at VII-5 to 6 (mining activity near breeding grounds could destroy entire mammal colonies); Dasmann, supra note 18 , at $1,3-4$ (unique biological ecosystems vulnerable because of simplicity and long isolation from evolutionary competition). For articles detailing environmental damage already noted around scientific stations in Antarctica, see Dayton \& Robilliard, McMurdo Sound, in Frozen Future, supra at 410; Fredrickson, Hallett Station, in id. at 416 .

110. See, e.g., P. Jessup \& H. TAubenfeld, supra note 21, at 85-110 (numerous international organs dealing with matters of international concern). It has been suggested that if a "well-developed international community" had existed at the time of European colonial discoveries three centurics ago, "discovered" lands "might have been attached to the community instead of to any one claimant," and that the opportunity should not be lost today to use new international institutions to exercise authority over the "one . . . land area remaining" outside national control. Commission to Study the Organization of Peace, Strengthening the United Nations 207 (1957). 


\section{A. Treaty Affirmation of Common Rights in Antarctica}

The Antarctic Treaty, signed in 1959 by representatives of twelve "Contracting Party" states, including all states claiming exclusive territorial rights, ${ }^{111}$ was designed to promote international scientific cooperation in Antarctica ${ }^{112}$ and to preserve Antarctica for peaceful uses. ${ }^{113}$ Although by no means the sole source of law for Antarctica, ${ }^{114}$ the Treaty is the most comprehensive and widely accepted statement of the principles of international law considered applicable to Antarctica in 1959. ${ }^{115}$ These principles lend support to Antarctica's status as a site of common rights. ${ }^{116}$

\section{Common Governance of All of Antarctica}

The Antarctic Treaty extends no form of positive recognition to claims of territorial sovereignty in Antarctica. ${ }^{117}$ Although a ma-

111. The Antarctic Treaty was signed in Washington, D.C., by representatives of Argentina, Australia, Belgium, Chile, France, Japan, New Zealand, Norway, South Africa, the U.S.S.R., the United Kingdom, and the United States. See Antarctic Treaty Preamble; notes 6 \& 7 supra (identifying claimant and nonclaimant states). The United States, as convenor of the conference, chose these states to participate because of their prior history of activity in Antarctica. The United States had failed in an effort in 1948-1949 to convene a similar conference, excluding the Soviet Union. Hanessian, The Antarctic Treaty 1959, 9 InT'L \& CoMp. L.Q. 436, 439-44 (1960). Conference proposals met with a more favorable response following the I.G.Y., and careful preparatory discussions were held among the 12 participating states, now including the Soviet Union. See generally id. at 455-67.

112. See Antarctic Treaty art. II (freedom of scientific investigation to continuc); id. art. III (exchange of scientific information and personnel); id. art. IX(1)(b), (c) (instituting consultative procedure to facilitate scientific research and cooperation).

113. See Antarctic Treaty art. I(1) (banning military activity); id. art. V(1) (banning nuclear testing).

114. See p. 808 \& note 11 supra (role of custom in international law); pp. 808-14 and notes 12-26 \& $39-42$ supra (customary practice in . Intarctica as source of law).

115. See, e.g., Antonsen, Natural Resources and Problems of Development, 9 CooperaTION \& CoNfLICT 179, 181 (1974) (Antarctic Treaty "the only internationally recognized legal code for the continent"). For a brief synopsis of provisions of the Antarctic Treaty relevant to mineral resource activities, see Nansen Foundation Report, supra note 3, at 76.

116. Cf. Taubenfeld, supra note 21, at 314 (Treaty "regularizes" and "seeks to perpetuate" customary practices that existed before Treaty was signed, such as demilitarization, rights of inspection, free access for scientists, and absence of enforceable national boundaries). See also Lundquist, supra note 5, at 21 (Antarctic Treaty lends support to international status of Antarctica).

117. While not recognizing the validity of any territorial claims, the Treaty does provide that none of its provisions is to be interpreted as "a renunciation . . of previously asserted rights of or claims to territorial sovereignty in the Antarctic" or as "a renunciation or diminution ... of any basis of claim," and that "[n]o acts or activities taking place while the present Treaty is in force shall constitute a basis for asserting, supporting or denying a claim to territorial sovereignty in the Antarctic or create any rights of sovereignty in the Antarctic." Antarctic Treaty art. IV. These provisions, most often understood as placing a "freeze" or "moratorium" on territorial issues, were the result of a compromise between claimant and nonclaimant states. Sollie, supra note 67 , at 19-20. This compromise has been sharply criticized as a "nonsolution, a . . . constructive evasion" of the territorial issue, id. at 19; as casting the issue into a "purgatory of ambiguity," Note, 
jority of states involved in Treaty negotiations in 1959 entertained such claims, ${ }^{118}$ the consultative structure that emerged from those negotiations holds authority to formulate policy for all of Antarctica and recognizes no special powers of states within claimed sectors. Military activity, a common symbol of a state's sovereignty over territory, is banned throughout Antarctica, ${ }^{110}$ and the right to exercise jurisdiction over observers and certain scientific personnel is granted to states on the basis of nationality rather than territorial location..$^{120}$ The Treaty's nonrecognition of all forms of exclusive territorial administration and the practice of Party states in working within the Treaty's unitary structure of governance since 1959 have greatly diminished the credibility of all exclusive claims in Antarctica ${ }^{121}$ and have laid the foundation for full internationalization. ${ }^{122}$

supra note 1, at 379; and as stating what the Treaty does not mean on territorial rights, without stating "what it does mean," Ratification Hearings, supra note 37, at 13 (statement of Sen. Gruening). But see note 38 supra (nonrecognition of territorial claims is not neutral in effect, but wcakens claims and enhances trend toward internationalization).

118. See note 111 supra (listing 12 Treaty Confcrence Parties); note 6 supra (seven claimant states).

119. See Taubenfeld, supra note 21 , at 283 (Treaty ban on military activity in Antarctica "is clearly a real derogation from 'sovereignty;' a self-denying rule of substantial potential importance").

120. See Antarctic Treaty art. VIII(1) (designated observers and scientific personnel on exchange between stations). The Treaty does not specify who shall exercise jurisdiction over persons not designated as official obscrvers, e.g., persons of different nationality participating jointly in an expedition, or even persons of the same nationality lodged together in a single scientific station. Hanessian, supra note 111, at 472. See generally Hambro, supra note 100 , at 223-24 (risk of jurisdictional conflict); Skagestad \& Traavik, supra note 85 , at 95 (threat of "continued anarchy" in unresolved jurisdictional and sovereignty claims). Several alternative theorics of jurisdiction in Antarctica have been propounded. See, e.g., Nansen Foundation Report, supra note 3, at ii; Note, supra note 68, at 186-92. But, except in those situations provided for by Treaty, the actual practice has been for each state to exercise jurisdiction over all persons of that state's nationality, totally disregarding factors of territorial location and sector claim. J. KISH, supra note 41 , at 117 . Cf. Note, supra note 68, at 194 (nationality, not geography, only feasible basis for exercise of juriscliction in Antarctica). This jurisdictional practice has been regarded as tacit recognition of the invalidity of exclusive claims. See J. KISH, supra note 41 , at 120-21 (absence of customary rights of territorial jurisdiction shows lack of sovereign rights); Hayton, The Antarctic Setllement of 1959, 54 AM. J. INT'L L. 349, 361 (1960) (jurisdictional system a "major infringement" on sovereign claims, a "real concession" by claimant states).

121. See Ratification Hearings, supra note 37, at 53 (statement of P. Jessup) (Treaty regime to have effect of neutralizing claims and barring eventual sector fragmentation); J. KisH, supra note 41, at 77-78 (freeze on claims "consolidates" absence of sovereignty).

122. See Ratification Hearings, supra note 37, at 4 (statement of Sen. Engle) (Treaty to "extinguish national claims once and for all" and frecze on claims to lead to indefinite "international control"). Some commentators have argued that the effect of the Treaty regime will be the "de facto internationalization" of Antarctica. See, e.g., C. BEEBY, supra note 30, at 17; Sollie, supra note 34, at 139 (formal reservations in Treaty cannot halt effects of freeze on sovereignty claims and of "continued international cooperation over a long period"); cf. Note, supra note 1, at 403 (Treaty bar to vesting of sovereign rights allows international resource control). 


\section{Common Rights of Access}

Consistent with the principle of common governance, the Treaty sets no restrictions on the right of persons or groups of persons of every nationality to move freely and to establish settlements throughout Antarctica. For certain designated observers, the Treaty also explicitly guarantees rights of "complete freedom of access" to Antarctic installations and facilities of all countries. ${ }^{123}$ Rights of geographic mobility have been affirmed in practice by the uninterrupted mobility of scientists and the installation of new research facilities in all regions of the continent ${ }^{124}$ and by the cautious but accommodating reception extended to multinational tourist groups. ${ }^{125}$

\section{No Exclusive Rights to Resources}

The Treaty recognizes no claims of exclusive right to Antarctic resources. ${ }^{126}$ By establishing principles of common governance and access, the Treaty lays a necessary foundation for, but does not clearly articulate, the principle that Antarctic resources belong to mankind generally. Resolutions passed by Treaty Parties since 1959 affirm the interest of a wide community of states in the protection and use of Antarctic resources. ${ }^{127}$

123. Treaty Consultative Parties, see p. 833 infra, may participate in this inspection system. Antarctic Treaty art. VII(1). The system has been heralded as one of the Treaty's major innovations. See generally Hanevold, Inspections in Antarctica, 6 Cooperation \& Conflict 103 (1971); Simsarian, Inspection Experience Under the Antarctic Treaty and the International Atomic Energy Agency, 60 Ax. J. INT'L L. 502 (1966). A number of successful inspections have been carried out since 1959. See, e.g., Hanevold, supra at 108; Swithinbank, A Year With the Russians in Antarctica, 132 Geocraphical J. 463 (1966). Inspections have been described as placing a major limitation on pretensions of national sovereignty, Hayton, supra note 120 , at 361 , as indicating a "partial surrender of sovereignty" by claimants, duburn, White Desert, supra note 30 , at 239 , and as showing presence of an effective "international regime" in Antarctica, J. KIsH, supra note 41, at 121-22.

124. Practice under the Treaty regime is consistent with the history of free mobility and settlement in Antarctica. See pp. 810-11 \& notes $19-26$ supra. See generally Goldblat, Troubles in the Antarctic?, 4 Bull. of Peace Proposals 286, 286 (1973) (territorial claims of less active states rendered untenable by access afforded more active parties); McDougal, Lasswell, Vlasic \& Smith, supra note 51, at 568-69 (Treaty promotes principle of "inclusive access" to Antarctica).

125. See note 5 supra.

126. The Treaty is totally silent on the specific issue of rights to resources in Antarctica. See Hambro, supra note 100, at 221 (no agreement reached on resource issues at Treaty Conference). In 1960 it was feared that the Treaty's silence would lead to constant "quarreling [among nations] about who owns which mine or well." Ratification Hearings, supra note 37, at 86 (statement of E. Kendall). But see note 127 infra (effect of Treaty regime has been to advance the principle of common heritage to resources).

127. See, e.g., Ninth Consultative Report, supra note 5, fi II-Rec.IX-1(4)(iv) (Consultative Parties not to "prejudice the interests of all mankind" in "dealing with the question of mineral resources in Antarctica"); id. II II-Rec.IX-2(III)(2)(a) (possible convening of "international ... convention" to establish "definitive regime" for conservation of Antarctic marine living resources). 


\section{Shared Rights in Decisionmaking}

The Treaty provides for equal participation by a set of Consultative Parties ${ }^{128}$ in all deliberations concerning Antarctica and requires that all recommendations passed at periodic meetings ${ }^{129}$ be unanimously approved by Consultative Party governments before taking effect. ${ }^{130}$ The Treaty thus bars usurpation of policymaking authority by single Party states and, despite certain stipulations that bar many Party states from gaining Consultative status, ${ }^{131}$ points the way toward adoption of more inclusive forms of Antarctic decisionmaking in the future. ${ }^{132}$

\section{Common Interest in Environmental Protection}

The Treaty bans nuclear explosions and the disposal of radioactive waste material in Antarctica ${ }^{133}$ and identifies the "preservation and conservation of living resources" as an appropriate subject of consultation among Party states. ${ }^{134}$ Since 1959 , the Consultative Parties have enacted a variety of measures to protect the Antarctic environment ${ }^{135}$ and have encouraged participation by non-Treaty Parties in the enforcement of those measures, ${ }^{136}$ thus affirming the common in-

128. See p. 833 \& note 139 infra (explaining Consultative status); notes 6 \& 7 supra (listing Consultative Parties).

129. See Antarctic Treaty art. IX(1) (Consultative Party meetings at "suitable intervals"); Skagestad, The Frozen Frontier: Models for International Cooperation, 10 Cooperation \& CONFLICT 167, 171 (1975) (consultative process in action). To facilitate scientific cooperation, representatives of scientific organizations of Consultative Party states also meet biannually as the Scientific Committee on Antarctic Research (SCAR), a subcommittee of the International Council of Scientific Unions (ICSU), a nongovernmental organization. Id. at 171-73; Hanevold, supra note 34, at 189. Consultative Party representatives and members of SCAR work closely together. See, e.g., Ninth Consultative Report, supra note 5, If II-Rec.IX-2(I)(2)-(4) (approving BIOMASS, supra note 2 (SCAR research proposal)).

130. See Antarctic Treaty art. IX(4). But see Hanevold, supra note 34, at 197 (unanimity rule may prevent discussion and resolution of controversial questions); Hayton, supra note 120 , at 364 (unanimity rule produces "weak" and "permissive" administrative system).

131. See pp. 833-34 \& notes 139-41 infra.

132. See, e.g., Sollie, supra note 34 , at 136 (multinational Treaty consultations have set a procedural norm of cooperation and reinforced a "legal order . . . that cannot completely be disregarded in the future").

133. Antarctic Treaty art. V(1); cf. Sollie, supra note 67, at 19 (nuclear testing provisions of Antarctic Treaty art. $V$ superseded by Nuclear Test Ban Treaty of 1963).

134. Antarctic Treaty art. IX(I)(f).

135. See, e.g., Ninth Consultative Report, supra note 5, ff $\mathrm{I}(13)(\mathrm{i}) \cdot(\mathrm{v})$ (reviewing measures taken to protect flora and fauna and to safeguard sites of special ecological, scientific, and historic interest, and adoption of new environmental Code of Conduct); id. II-Rec. IX-5 (declaration on protection of Antarctic environment).

136. See id. If I(14) (encouraging non-Consultative Party states active in Antarctica to adopt all Consultative Party Recommendations, including those pertaining to environment); id. I II-Rec.IX-2(II)(1)(c) (urging non-Treaty Parties to follow Consultative Party guidelines on conservation of marine living resources). 
terest and the need for involvement of many states in Antarctic environmental planning.

\section{Common Interest in Peacekeeping and Scientific Information-Sharing}

The Treaty affirms the principle that peaceful use of Antarctica is "in the interest of all mankind" and in harmony with the principles of the United Nations Charter. ${ }^{137}$ The Treaty also calls for full cooperation with international agencies in gathering and sharing scientific information, ${ }^{138}$ thus further integrating the Treaty's regime into international processes and administration.

\section{B. Failings of the Treaty's Consultative Structure}

The Antarctic Treaty articulates principles and fosters practice in accord with common rights in Antarctica, but is seriously flawed as a mechanism for the protection and implementation of those rights. Most critically, the Treaty fails to provide for full international participation in its structure of administration. As a result, the benefits of Antarctic resource development may unfairly be denied to developing states, and the plans and agreements of the Treaty Parties will fail to bind non-Party states.

The Antarctic Treaty entitles only two categories of states to share in policymaking as "Consultative Parties": states among the original twelve Treaty signatories, and subsequent signatories that demonstrate "interest in Antarctica by conducting substantial scientific research activity." 139 Although the Consultative status of the twelve original Parties is irrevocable, a Party in the second category may lose its Consultative status at any time upon a showing that its scientific "interest" in Antarctica has diminished. ${ }^{140}$ Under these provisions, only one of

137. Antarctic Treaty Preamble. See also Ninth Consultative Report, supra note 5, IIRec.IX-1 (preamble) (Treaty establishes "regime for international cooperation in Antarctica," promoting "international harmony" in accord with U.N. Charter).

138. Antarctic Treaty art. III(2). See also BIOMASS, supra note 2, at 61 (chart showing relationship of SCAR and Antarctic Treaty regime to international organizations carrying on Southern Ocean research programs and calling for "effective co-ordination" of all programs).

139. Antarctic Treaty art. IX(2). The article provides that examples of such "substantial activity" include the "establishment of a scientific station or the dispatch of a scientific expedition." Id. However, the standard of accession to Consultative status in practice has been establishment of a year-round scientific station. See note I4I infra. Policymaking is carried on through periodic meetings, see note 129 supra, to which only Consultative Parties may appoint representatives, see Antarctic Treaty art. IX(I), (2).

140. Antarctic Treaty art. IX(2) (Consultative status retained only "during such time" as substantial research activity continues). 
the seven states to accede to the Treaty since the initial signing by the twelve in 1959 has been granted Consultative status, ${ }^{141}$ while several of the twelve original signatories retain Consultative status despite the effective termination of their Antarctic programs. ${ }^{142}$ As a result, Treaty consultations today include a narrow group of thirteen states that is both over- and under-inclusive with respect to demonstrations of scientific interest, ${ }^{143}$ and seriously under-inclusive with respect to commercial and environmental interest in Antarctica. ${ }^{144}$

141. The seven Treaty Parties not among the original signatories are Poland (1961), Czechoslavakia (1962), Denmark (1965), the Netherlands (1967), Romania (1971), East Germany (1974), and Brazil (1974); $c f$. U.S. Def'T of State, Treaties in Force 315 (1976); Note, supra note 68 , at 173 n.j. Of these states only Poland has been granted Consultative status. The Consultative Parties in 1977 adopted a special "procedure of consultation" by which to "acknowledge" the accession of new states to Consultative status. See Final Report of the Special Antarctic Treaty Consultative Meeting, July 25, 27, 29, 1977 (on file with Yale Law Journal). Under the adopted procedure, a state giving notice that it "considers itself entitled" to assume Consultative status must (a) accede to the Treaty; (b) supply information concerning the "content and objectives of its scientific programme" in Antarctica; and (c) allow Consultative Parties to inspect any facilities it may have in Antarctica. Id. If I(I), (2). Consultative Parties may also "urge" the state to "make a declaration of intent to approve" all Recommendations of previous Consultative Meetings passed and ratified. Id. . $\mathrm{I}(2)$. In acknowledging that Poland had fulfilled the necessary requirements, the Consultative Parties noted that Poland had demonstrated its "interest" in Antarctica by establishing a "permanent scientific station . . . in the Antarctic Treaty Area," $i d$. III, thus suggesting that the mere "dispatch of a scientific expedition" in Antarctica, proposed in Antarctic Treaty art. $\mathrm{IX}(2)$ as one means of demonstrating scientific interest, would not be sufficient to qualify a state to gain Consultative status. See note 15 supra \& note 143 infra (several states have "dispatched" or participated in joint scientific expeditions in Antarctica but do not hold Consultative status); Sellin Interview, supra note 3 ("standard of accession to Consultative status seems to be having a scientific land station; otherwise interest in harvesting krill could be deemed 'scientific' " and many states could thereby gain Consultative status, a result that would be "met with objection by some claimant states who are concerned about enlarging the size of the Consultative group"). See generally Goldblat, supra note 124, at 288 (exclusive nature of Treaty's Consultative structure may discourage states from becoming Treaty Parties).

142. Belgium maintains no station of any kind at any time of year in Antarctica, and Norway maintains only two seasonal stations, each with total in-season populations of no more than seven persons. Antarctic Map, supra note 24. Under the standard of "substantial scientific research activity" applied to new Consultative Parties, see note 141 supra (maintaining "permanent scientific station"), the Consultative status of neither of these states would be "acknowledged" should it seek that status today. Other states would be borderline cases. Although Poland, the new Consultative Party, operates two year-round stations in Antarctica, three states-South Africa, New Zealand, and France-each operate only one such station, with maximum resident populations of only 24, 24, and 40 , respectively. Antarctic $M a p$, supra note 24.

143. See note 142 supra (over-inclusiveness). The Consultative group is also underinclusive with respect to scientific interest because several states that have been scientifically active in Antarctica do not have Consultative status. See, e.g., 18 PoLAR REC. 379 (1977) (Italian scientific expedition to Antarctica conducts numerous experiments, establishes temporary base); N.Y. Times, Dec. 12, 1976, at 1, col. 3 (Denmark, Switzerland, and West Germany participate in joint scientific project).

144. See note 2 supra (two states that are not even Treaty Parties-West Germany and Taiwan-harvesting or prospecting for krill in Antarctica); pp. 826-27 \& notes 103-09 supra (integrated world economy and ecology create universal interest in Antarctic resources and environment). See generally Ratification Hearings, supra note 37, at 26-27 
These discrepancies arise because the method of accession to Consultative status was devised at a time when Antarctica was primarily of interest as a laboratory for scientific research, and commercial and environmental concerns were merely speculative. Today, however, interest in Antarctica is no longer exclusively scientific. Scientists now lead the search for minerals, oil, and other resources, and aid in calculating the environmental risks of exploitation. ${ }^{145}$ The pursuit of scientific knowledge in Antarctica generally has become far less urgent than the resolution of questions concerning rights to Antarctic resources and tradeoffs between resource development and environmental protection.

Today, every world state has an interest in consultations that reach these questions. To bar from participation states with no Antarctic "scientific" program is no longer consistent with the focus of Treaty Party discussions. Such exclusion also concentrates the benefits of resource information and decisionmaking, and potentially also of resource use, in a small circle of states-for the most part, states fortuitously located near to Antarctica or with early histories of Antarctic exploration. ${ }^{146} \mathrm{New}$, developing states that have no resources and per-

(statement of Rep. Pillion) (Contracting Parties not the "legitimate parties in interest" to Antarctic decisionmaking, since several states with minimal or no experience in Antarctica included, others with greater experience excluded; with broad issues of rights at stake, scientific activity requirement is "untenable," "unprecedented," illogical, and "wholly contradictory" to principles of international law).

145. See, e.g., BIOMASS, supra note 2, at 38, 45-47 (SCAR document proposing study of means of harvesting and nutritional values of Antarctic sea life); Mineral Exploration, supra note 3, at \II(A)(iii)(13) (geologic drilling experience could aid exploration for and exploitation of hydrocarbons). See also Auburn, White Desert, supra note 30, at 237 (trend away from "purely scientific research to more utilitarian investigations" in Antarctica); Nansen Foundation Report, supra note 3, at 72 (commercial and scientific explorations "use the same techniques"). United States officials agree that Antarctic projects without commercial motive may eventually bring significant economic benefits. See Wulf Interview, supra note 40 National Science Foundation "funds no projects with the direct object of finding resources," but "enough is already known about mineral locations and concentrations on land for a company to make prospecting decisions."). See also Sellin Interview, supra note 3 ("It is sometimes difficult to know where science stops and commercial activity begins."); Antarctic Hearing, supra note 3, at 16 (statement of Dixy Lee Ray, Ass't Sec'y of State) (United States policy is "to encourage scientific parties to do exploratory work" for "resources that might be discovered" in Antarctica). Ironically, a recent United States-funded environmental impact assessment, ExviroNmENraL IMPACTs, supra note 3 , is the most comprehensive source available on Antarctic resource values and exploitation technologies. See, e.g., id. at IV-1 to 19 (examination of resource surveying procedures, logistical and personncl needs for resource exploration, drilling and mining techniques, power sources and operational facilities needed, transportation systems for ores, and shipping facilities); $i d$. at VI-I to 20 (estimating costs of production and future dates when exploitation could become profitable).

146. See pp. $815-22$ \& notes 44-85 supra (contiguity, discovery, and occupation theories cited as foundation for territorial claims and for Consultative status of seren states); note Ill supra (nonclaimant states invited to attend Treaty Conference because of cxploration activ ity). 
sonnel to spare on scientific programs in Antarctica may be barred indefinitely from shaping decisions that could vitally affect their economies and general welfare. ${ }^{147}$ Such a program of exclusion seriously undermines the legitimacy of the entire Antarctic Treaty scheme as an instrument of international law. ${ }^{148}$

The problem of Treaty exclusivity is aggravated by the secrecy of Treaty consultations, ${ }^{149}$ which reflects the Parties' fears that uninvited outside interests will meddle in Antarctic affairs. ${ }^{150}$ Although

147. See pp. 826-27 \& notes $103-09$ (economic and environmental factors at stake in Antarctica affect all countries). See also Hanevold, supra note 34, at 186 (small states lack economic capability to establish, support, and staff scientific stations in Antarctica; substantial presence in Antarctica possible only for "super powers"); see generally Skagestad, Small States in International Politics: A Polar-Political Perspective, 9 CoOperation \& Conflict 185 (1974).

148. It has been proposed that Treaty exclusivity could be relieved simply by equalizing access to Consultative status. Goldblat, supra note 124, at 288 . But in view of Antarctic Treaty arts. IX(2) (prescribing scientific "admissions" test) and XII(1) (unanimity rule for Treaty amendments), it is unlikely that such a provision could be put into effect. More fundamentally, no proceduce of amendments to a pre-existing Treaty can accommodate the rights of all world states to participate in the initial structuring of a common-spaces regime. See pp. 853-54 \& notes 240-43 infra (need for international conference or exercise of authority over Antarctica by existing world body).

149. Treaty negotiations and deliberations have long been held away from public view. The "sixty preparatory meetings" to the Antarctic Treaty Conference in 1959, and the Conference deliberations themselves, were held "privately." Hanessian, supra note 111, at 466. Consultative Party meetings since 1959 also have been held behind closed doors. In 1976, for example, it was reported that the Consultative Parties had held a "secret meeting" to discuss the "possible exploitation of Antarctica's mineral resources," an issue "of such sensitivity that the 12 countries ... decided against issuing any communiqué or even signaling the presence of their representatives in Paris." N.Y. Times, July 14, 1976, at 5 , col. I. See also id., Oct. 9, 1977, $\S 4$, at 7, col. 1 (most recent Consultative Meetings behind closed doors); Nansen Foundation Report, supra note 3, at 84 (commercial development of any mineral in Antarctica could be "kept secret" for up to nine years of projected 20-year span of exploration and exploitation). Similarly, United States Antarctic policymaking, centered in the Departments of Defense and State and the National Science Foundation, Antarctic Hearing, supra note 3, at 3-4, with some participation by other agencies involved with "resources" and "environment affairs," id. at 12, has been criticized for being closed to public participation and review. See, e.g., Sierra Club Report, supra note 5, at 7 (United States Antarctic policymakers characterized as "small "club" " that carries on deliberations in "secrecy" and that suffers from lack of information and policy input from nongovernmental sources); cf. Sellin Interview, supra note 3 (United States is restrained by claimant states in efforts to open Treaty matters to public discussion).

150. Nansen Foundation Report, supra note 3, at 80-81 (Treaty Parties fear interference by non-Treaty Party states, United Nations, and private companies prospecting for resources). Discussion of Antarctic resource issues in an international forum such as the Third United Nations Conference on the Law of the Sea has been described as a particu. larly "chilling prospect" to Consultative Party diplomats. Rose, Conflicts in Establishing a Resource Regime 2 (July 15, 1976) (unpublished paper issued at Sierra Club Meeting) (on file with Yale Law Journal). Consultative Parties are "anxious not to raise a red flag for the Third World," Sellin Interview, supra note 3, and Consultative Party concern over Third World interference "contributes to the air of secrecy about resource negotiations," Wulf Interview, supra note 40 . Official concern about the threat of international interference in Antarctica is also suggested in Antarctic Hearing, supra note 3, at 16, 22 (colloquy between Sen. Pell and various State Dep't officials) (censors delete all responses 
the exclusivity is unjustified, fears of "intrusion" are not unwarranted since no provision of the Antarctic Treaty and no resolution passed by the Consultative Parties is formally binding under international law on states not Parties to the Treaty. ${ }^{151}$ The Treaty serves as a source of law generally in expressing principles of customary law and practice in Antarctica (for example, common rights of access and peaceful use), ${ }^{152}$ but an exclusive and self-perpetuating set of Treaty Consultative Parties has no authority to bind other world states to plans specifically allocating or regulating the use of resources that are not exclusively theirs. The common rights affirmed through history in Antarctica are shared equally by all world states and peoples and are not susceptible to administration and manipulation by unrepresentative groups. Without a valid base in authority, resource plans and regulations of the Treaty Consultative Parties bear little legal weight.

\section{Treaty-Based Resource Proposals}

Despite the lack of authority in Treaty Parties to regulate the use of Antarctic resources, three types of plans have been proposed for their consideration: a moratorium on resource development; "first come, first served" resource appropriation under Consultative Party regulation; and declaration of an exclusive Consultative Party "condominium" over all Antarctic resources. The implications of international law for these plans depend on the type of resource involved.

For resources that are, within limits, renewable-such as icebergs and marine living resources-only a "first come, first served" ("free")

by officials of U.S. Dep't of State to questions concerning United States policy on United Nations or Law of the Sea Conference consideration of Antarctic resource questions). It is also suggested by recent Consultative Party resolutions, see Ninth Consultative Report, supva note 5 , If I(14) (urging all states active in Antarctica to accede to the Antarctic Treaty), and Consultative Party Recommendations asserting "special" Consultative Party responsibility to regulate mineral derelopment of Antarctica, id. II-Rec.IX-1 (preamble), and "prime" responsibility for protection and conservation of the Antarctic environment, id. Ff II-Rcc.IX-2(III)(3)(a), II-Rec.IX-5(1). Sce also id. If II-Rec.IX-1(5) (reiterating need to safeguard juridical position of territorial clainant states in new Antarctic resource regime).

151. See, e.g., Hanessian, supra note 111, at 470; Rose, Antarctic Condominium: Building a New Legal Order for Commercial Inlerests, MARINE Trcir. Scr. J., Jan. 1976, at 19, 20.

152. See pp. 808-11 \& notes 12-26 supra (exercise of customary common rights in Antarctica); pp. $829-33$ \& notes $117-38$ supra (Treaty affirming principles of common rights and interests in Antarctica). Treaties are not binding on third parties unless regarded as stating general principles of intcrnational law. C. BEEBx, supra note 30 , at 17 . Commentators have noted that the Treaty, at least in many respects, does not state "general international law," see, e.g., Goldblat, supra note 124, at 288, and that therefore the Antarctic Treaty system is "not watertight" and not "enforccable crga omnes," Mouton, supra note 15 , at 259 . 
development plan is being seriously contemplated. ${ }^{153}$ Even if promoted by a body not universal in membership, such as the Consultative Party group, a plan for free development of renewable resources does not risk violation of common rights so long as discrimination against certain world states or interests, ${ }^{154}$ unacceptable environmental risks, ${ }^{155}$ and serious diminution in resource supplies ${ }^{156}$ are not involved. Generally, common rights are not violated by such a plan so long as irreplaceable resource interests are not threatened with destruction. The Consultative Parties have recognized that regulations pertaining even to renewable resources in Antarctica can take practical effect only if formulated and adopted by a community of states wider than that of the Consultative Parties. ${ }^{157}$ But common rights to resources are placed

153. See, e.g., Ninth Consultative Report, supra note $5, \llbracket \mathrm{I}(10)$ (harvesting of marine living resources not to be prohibited, since "rational use" not inconsistent with "conservation"); Scully Interview, supra note 2 (no moratorium likely to be called now for living resources, since new regulatory regime should be in place before large-scale exploitation begins). The most important of these marine living resources is krill. See note 2 supra. Krill supplies are replenishable even at high levels of harvesting, see BIOMASS, supra note 2, at 1 (possible 100 million ton annual harvest), and are a form of resource traditionally exploited freely, see Composite Text, supra note 52, art. 116 (right to fish on high seas); Scully Interview, supra note 2 (even common heritage of mankind concept does not bar free exploitation of resources of water column). Also, no plans have been considered yet to ban or restrict harvesting of renewable, nonliving resources, such as icebergs. See note 5 supra (iceberg resource prospects). Icebergs have been considered to be freely exploitable because they are currently in large supply, Lundquist, supra note 5, at 2-3, and are analogous to other renewable resources of the high seas, see id. at 23 (icebergs legally can be seized "like fish"). But cf. Christy, Fisheries: Common Property, Open Access, and the Common Heritage, in PACEM IN MAaribus 183, 206 (E. Borgese ed. 1972) (to protect common heritage, free and open access to renewable world fishing resources "must be closed and those that obtain the privilege of fishing must pay . . . some form of economic rent," thus providing "a more inclusive sharing in wealth").

154. Cf. Composite Text, supra note 52, art. $119(3)$ (high seas fishing regulations may not discriminate against any state).

155. Since environmental hazards may be involved in harvesting renewable resources, see BIOMASS, supra note 2, at 1 ("disastrous" ecosystem changes from over-exploitation of krill); Lundquist, supra note 5, at 6-7 (risks of iceberg towing), legal limits are imposed on levels of acceptable use, see p. 827 \& notes $105-09$ supra, p. 851 \& note 228 infra (rights and obligations of environmental protection that pertain to Antarctica).

156. Supplies of renewable resources are not inexhaustible. See BIOMASS, supra note 2, at 15, 16 (krill harvesting must proceed within limits); N.Y. Times, Nov. 11, 1976, at 40, col. 1 (editorial) (icebergs, like fish, may eventually be in short supply). Thus all harvesting parties are bound by a duty to conserve. See, e.g., Composite Text, supra note 52 , arts. 117-119 (duty to cooperate in conserving high seas living resources); Ninth Consultative Report, supra note 5, ff II-Rec.IX-2(II)(I)(b) (calling for "greatest possible concern and care" to avoid depletion of marine resources). Experience with other renewable resources in Antarctica suggests that serious losses result from unrestrained harvesting. See, e.g., K. Bertrand, supra note 39, at 3 (Antarctic fur seals reduced almost to extinction); ENvironmental. IMPACTs, supra note 3, at II-17 (whale stocks in Southern Ocean reduced from previous one billion to only 337,000 ).

157. See, e.g., Ninth Consultative Report, supra note 5, fIf II-Rec.IX-2(III)(2)(a), (c) (possible international "convention" to establish Southern Ocean marine resources regime, with participation by "States other than Consultative Parties which are actively engaged in research and exploitation of Antarctic Marine Living Resources," and, on 
in immediate jeopardy only by plans regulating the use of nonrenewable, and thus irreplaceable, resources such as oil and on-shore minerals. ${ }^{158}$

\section{Moratorium}

Under the first of the three plans proposed for nonrenewable resources, observers have called for a temporary moratorium on Antarctic mineral activities until environmental hazards are fully assessed ${ }^{150}$ and for a permanent moratorium leading to preservation of Antarctica as an "international park." 160 Scientific studies support the propositions that unregulated mineral activities in Antarctica risk irreversible environmental harm ${ }^{161}$ and that even the most careful regulation cannot fully preserve the Antarctic environment and ensure against accidents with serious effects. ${ }^{102}$ The Consultative Parties have shown

"observer basis," by "appropriate international organisations"); BIOMASS, supra note 2, at 60.63 (proposal for Southern Ocean scientific study endorsed by Consultative Parties, see note 129 supra) (encouraging participation in scientific programs by all "interested parties," including non-Treaty Party states and international organizations). See also Scully Interview, supra note 2 (standard of accession to the living resources regime is "problematic," but "it may be necessary to include all 'interested' states").

158. See Scully Interview, supra note 2 ("In Antarctica, questions of sovereignty would definitely be raised by the exploitation on the continent or continental shelf of mineral resources such as oil, because these resources are depletable."); $c$. Composite Text, supra note 52, arts. 133-192 (special legal provisions and institutional arrangements for all sea mineral resources "in situ," such as petroleum, gas, steam, and other liquids or gases, and for all "useful" solid minerals on, near, or below surface of seabed).

159. See, e.g., N.Y. Times, Sept. 1, 1977, at 20, col. 1 (director of Sierra Club International calls for "moratorium on the exploitation of mineral resources [in Antarctica], until it is established that" such exploitation will have "no significant adverse environmental impact"); N.Y. Times, Aug. 29, 1975, at 28, col. 2 (quoting executive director of United Nations Environmental Program, calling for moratorium "until its consequences can be fully evaluated" and "protection of the environment is assured").

160. See, e.g., Skagestad \&. Traavik, supra note 85, at 94 (goal of protecting "intact natural environment" of "new territories," including Antarctica, as "scientific laboratories, natural museums, or recreational resorts in their original state"); N.Y. Times, Apr. 26, 1975, at 27, col. I (400 delegates from 75 countries to World Conference on National Parks urge establishment of Antarctic world park under United Nations direction, to protect continent's "'unaltered natural ecosystem'"). It has also been argued that mining and other economic activity on a large scale could so injure the Antarctic environment as to contradict "underlying aims" of the Antarctic Treaty and thus be barred. Hambro, supra note 100 , at 223 .

161. See note 109 supra (environmental hazards of Antarctic mineral development). The possibility of environmental loss is greatly increased if regulations are not implemented and enforced from the first stage of exploration through the end of exploitation. Environmental IMPACTS, supra note 3, at XI-1. See also id. at Summary $\mathrm{xx}$ (without effective regulation, no economic incentive exists for concern about effects of oil spills and chemical waste disposal); Mineral Exploration, supra note 3, I I(4) (environmental safeguards necessary prior to exploratory drilling for hydrocarbons).

162. See, e.g., ENvironmental. Impacts, supra note 3, at Summary $\mathrm{xx}$ (serious environmental risks remain even with "optimum safety procedures"). 
little interest in proposals for an Antarctic world park, ${ }^{163}$ however, and have extended special regulatory protection only to limited regions. ${ }^{164}$ The Parties have called for voluntary self-restraint in mineral development activities only until the implementation of a Consultative Party mineral "regime," $16 \tilde{s}$ and they have conducted detailed technological and environmental studies contemplating future exploitation. ${ }^{166}$ But because of the exclusivity of the Treaty's Consultative structure and the shared interests at stake, the Consultative Parties have no authority to bind world states to any measures balancing economic and environmental interests in Antarctica. ${ }^{167}$ Scientists and environmentalists interested in the preservation of Antarctica thus should urge a world body with the right to exercise full authority in Antarctica $^{168}$ to adopt the preferred measures.

Nevertheless, until a more fully representative regime is instituted for Antarctica, principles of international environmental law bar all world parties from engaging in environmentally hazardous forms of mineral exploration in Antarctica, ${ }^{169}$ and common rights to Antarctic resources bar all exploitation. ${ }^{170}$ Under international law there is in

163. Compare Ninth Consultative Report, supra note 5, If I(13)(i) (recalling Consultative Party designation of Antarctica as "Special Conservation Area") with Nansen Foundation Report, supra note 3, at 83 (uncertain import of Special Conservation Area designation to Antarctic commercial activities).

164. See, e.g., Ninth Consultative Report, supra note 5, IT I(13)(ii), (iv) (recalling Consultative Party designation of "Specially Protected Areas" and "Sites of Special Scientific Interest" to preserve ecological and scientific values, and measures to protect historic monuments); Nansen Foundation Report, supra note 3, at 83 (concluding that "mining would not be permitted in Specially Protected Areas and Sites of Special Scientific Interest" and that "[o]ther parts of the Antarctic Treaty area might be reserved for noncommercial activities").

165. Ninth Consultative Report, supra note 5, ff II-Rec.IX-1(8) (urging all world parties to "refrain from all exploration and exploitation of Antarctic mineral resources" until "timely adoption of an agreed regime concerning Antarctic mineral resource activities"). Unlike this system of "voluntary self-restraint," a moratorium on mineral activities would be "binding [on the respective Consultative Party states] and would require domestic legislation." Sellin Interview, supra note 3. The Consultative Parties "appear to be less interested in a moratorium now than two years ago because of concern that imposing a moratorium could slow down the progress toward establishing a resource regine." Id. Cf. Antarctic Hearing, supra note 3, at 6-7 (United States opposes formal moratorium but favors interim policy of voluntary nonexploration and nonexploitation).

166. See Mineral Exploration, supra note 3, fff II(A), (B), (C) (thorough study of "present state of technology for exploration and exploitation of minerals in the Antarctic," environmental impact of such activity, and measures for "prevention or restoration" of environmental "damage"); cf. Environmental Impacts, supra note 3 (exhaustive review of technological and environmental factors involved in Antarctic mineral use, prepared for U.S. Dep't of State).

167. See pp. 833-37 \& notes $139-52$ supra.

168. See pp. 853-54 \& notes 240-43 infra (United Nations, international conference, or seabed regime).

169. See p. 827 \& notes 105.09 supra, p. 851 \& note 228 infra (general international and common-space environmental principles applicable to Antarctica).

170. See p. 850 \& notes $216-19$ infra. 
effect today, therefore, a temporary de facto moratorium on most exploration and all stages of exploitation of nonrenewable Antarctic resources.

\section{First Come, First Served Resource Use}

In contrast to the moratorium proposal, a second approach would open Antarctica to free appropriation of mineral resources, subject only to certain Consultative Party safeguards. The United States, for example, argues that in the absence of valid territorial claims in Antarctica $^{171}$ and with no Treaty provisions clearly governing resource use, ${ }^{172}$ Antarctic resources must be analogized to those of the high seas $^{173}$ and free access to exploit those resources must be guaranteed. ${ }^{174}$ The United States and other industrialized states have a strong economic interest in free appropriation, since these states have the procurement technology and capital needed for exploitation. Free appropriation of Antarctica's nonrenewable resources, however, could allow economically developed states to deplete valuable supplies before developing states can take a fair share. ${ }^{175}$ Antarctica's nonreplenishable reserves of oil and coal thus cannot be analogized to fish of the high

171. See note 40 supra (consistent United States policy of nonrecognition of Antarctic territorial claims).

172. See p. 831 \& notes $126-27$ supra (Treaty silent on resource issues but lays foundation for principle of common-heritage rights).

173. See Scully Interview, supra note 2 ("The juridical view of the United States is that Antarctica is analogous to the high seas and that for this reason resource rights are first come, first served, with only a duty to conserve, as in the case of high seas fishing.")

174. United States policy was stated in 1975 as favoring "[f]ree access to develop natural resources" in Antarctica and the adoption of "uniform and nonpreferential rules applicable to all countries and nations for ... development of resources." Antarctic Hearing, supra note 3, at 5 . More recently it has been stated that "the U.S. government has not developed a final, detailed position with regard to mineral resource rights in Antarctica," Interview with Jean Bailly, Office of the Legal Adviser, U.S. Dep't of State (Nov. 9, 1977) (notes on file with Yale Law Journal) [hereinafter cited as Bailly Interview], but at Consultative Party meetings the United States advocates a "free resource access position," Wulf Interview, supra note 40, with guarantees of open and "nondiscriminatory access to resources," Sellin Interview, supra note 3 . Since no formal moratorium has been agreed on to bar resource development, private companies face no legal sanctions should they decide to proceed with mineral activities at the present time. The United States, however, "supports the policy of voluntary self-restraint reflected in Consultative Party resolutions and would discourage mineral exploration and exploitation activities in Antarctica by United States companies." Bailly Interview, supra. The United States also has refused to grant an exclusive resource license to a private company seeking to prospect for oil in Antarctica, Antarctic Hearing, supra note 3, at 18, and has disavowed any intention to proceed unilaterally with commercial development plans, id. at 6-7. But see note 145 supra (United States sponsorship of Antarctic scientific and enrironmental research projects with possible resource implications).

175. Cf. McDougal, Lasswell, Vlasic \& Smith, supra note 51 , at $586-87$ (generally "[t]o open a scarce stock of minerals to free access by all participants with capabilities for exploitation" could "invite a mad scramble in which each participant seeks to grab as much as possible without concern for impact upon others or common interest"). 
seas; a better comparison is drawn to nonrenewable deep seabed resources, widely identified as belonging to all states and peoples in common and not available for private appropriation. ${ }^{170}$ Since Antarctica is a site of historic common rights and since no rights to Antarctic resources are held exclusively, ${ }^{177}$ free appropriation of these resources even under Consultative Party guidelines is legally precluded. Only a fully representative regime can determine whether these nonrenewable resources should be used at all, and if so, in what manner and according to what formula of benefit distribution.

Leading toward possible implementation of the third resource plan, the condominium, Treaty Consultative Parties have called for "intensified consultations" among themselves to determine the nature of a future mineral resource "regime." 178 The principles adopted by the Consultative Parties to guide this regime are inherently contradictory and reflect the serious differences of opinion that exist within the Consultative group. ${ }^{179}$ Yet unanimity exists insofar as no Consultative Party has publicly proposed inviting other world states or organizations to join in the consultations, ${ }^{180}$ and none of the Parties is openly advocating implementation of a regime that would fully protect Antarctic common rights. ${ }^{181}$

\section{Condominium}

Under the condominium plan, the Consultative Parties would declare Antarctica to be their joint and exclusive property, with full sovereign and beneficial rights vested only in themselves. ${ }^{182}$ This approach is attractive to some Consultative Parties since it would enhance the apparent authority of the Consultative Parties in Ant-

176. See notes $207 \&$ 216-19 infra.

177. See p. 831 and notes 126 \& 127 supra, p. 850 \& notes $216-19$ infra.

178. Ninth Consultative Report, supra note 5, IT II-Rec.IX-1(6)-(8).

179. Compare id. ff II-Rec.IX-1(5) (Antarctic Treaty provisions freezing territorial claims not to be "affected by the regime") with id. I II-Rec.IX-1(4)(iv) (mineral resource measures not to "prejudice the interests of all mankind in Antarctica").

180. See, e.g., Wulf Interview, supra note 40 (Antarctic mineral resource questions may be decided in "small political arena" because of "disappointing experience with seabed regime negotiations at the Law of the Sea Conference and other international economic fora.")

181. See Sellin Interview, supra note 3 ("With regard to mineral resources, a concept of common heritage of mankind in the sense of common ownership is not under discussion by the Consultative Parties.")

182. The term "condominium" in international law has been defined as " $t]$ he conjoint exercise of sovereignty over a region by two or more states," I G. HackworTH, supra note 16, at 56, with condominium co-oyners holding exclusive rights to give concessions for resource exploitation and to share the royalties, Hambro, supra note 100 , at 224. Sec generally P. JESSUP \& $\mathrm{H}$. TAUBENFELd, supra note 21 , at $11-49$ (precedents of international condominia). 
arctica. A condominium also promises to reconcile conflicting Consultative Party territorial claims by asserting indivisible, collective sovereign rights to all of Antarctica and by distributing the proceeds of resource development among co-owners. ${ }^{183}$

Yet an exclusive condominium scheme in Antarctica would shock the conscience of the world community ${ }^{184}$ and would raise the "red flags" of alarm that the Consultative Parties through so many years of secret deliberations have tried to keep low. ${ }^{185}$ Furthermore, an Antarctic condominium is unacceptable under international law. If the Consultative Parties have no authority either to impose a resource moratorium or to begin exploitation of certain Antarctic resources, certainly they have no authority to proclaim sweeping rights of sovereignty or to exercise exclusive resource rights in perpetuity under cloak of condominium. Equally inapplicable to a zone of common rights is the condominium's premise of "earned rights": that no entitlements are shared by states too little involved in Antarctica to have been selected as Treaty Conference Parties in 1959 or to have mounted "substantial" scientific programs since 1959.186 Instead, rights in Antarctica are enjoyed equally by all states and peoples that share in a common world heritage. ${ }^{187}$

183. Proponents of the condominium concept in Antarctica argue that only the 12 original Treaty signatories should be members, Hambro, supra note 100 , at 225 , that the scheme is workable since even states not Parties to the Antarctic Treaty could somehow be bound, Nansen Foundation Report, supra note 3, at 81 , and that a condominium would reflect the true "national interests of the [12 original] Contracting Parties" through its exclusion from Antarctica of all other states, Rose, supra note 151, at 25-27. See also Interview with John Norton Moore, Walter L. Brown Professor of Law, University of Virginia Law School, formerly United States Ambassador to the Third United Nations Conference on the Law of the Sea (Jan. 23, 1978) (notes on file with Yale Law Journal) ("The most desirable solution in Antarctica is a resource, scientific, and environmental condominium among the primary Treaty Parties, involving exclusive resource development rights for just those Parties.") [hereinafter cited as Moore Interview]; cf. Auburn, supra note 14 (arguing effective presence of joint United States-New Zealand condominium over Antarctic sector claimed by New Zealand). Although claimant states would undoubtedly prefer a condominium to international rule in Antarctica, a condominium could be expected to meet with some objection from those states since it would take the "economic incentive, if not the substance," out of individual sector claims. Lundquist, supra note 5, at 10-11.

184. See, e.g., Antarctic Hearing, supra note 3, at 1 (Sen. Pell, Chairman, Subcomm. on Oceans and International Environment of the Senate Comm. on Foreign Relations) (opposing any resource regime "within the context of the Antarctic Treaty," fearing "charges throughout the international community that the United States is seeking to carve up that continent for the use of itself and a few other, primarily developed, nations"); Finch, Three Problems of International Law, 4 Cursos Monograficos 1, 42 (1954) (unlikely that "excluded nations would agree" to application of "doubtful rules of international law" by parties scrambling for control over Antarctica).

185. See notes $149 \& 150$ supra.

186. See p. 833 \& note 139 supra (only states meeting the prescribed requirements to enjoy rights of Consultative status).

187. See pp. 847-48 \& notes 206-11 infra (concept of common heritage of mankind applicable to Antarctica). For other criticisms of the condominium proposal, see $P$. Jessup 
Regulatory provisions effecting a "de facto" condominium may be more likely to emerge from Consultative Party negotiations. ${ }^{188}$ Measures have been proposed that side-step the sovereignty issue by providing universal rights of access for certain purposes $^{180}$ and that aim, through revenue sharing, to assuage world demands for a share in Antarctic resource benefits. ${ }^{190}$ Nevertheless, the Consultative Parties under this approach would retain full administrative authority. These Parties alone would regulate the exercise of rights of access and determine the proportion of resource revenues to be "shared" with the rest of the world community. ${ }^{191}$ Such a de facto condominium is no more acceptable under international law than a de jure condominium. Since common rights in Antarctica cannot be exchanged for partial ones, the Consultative Parties have no authority to determine which rights and benefits are to be enjoyed in Antarctica by which other states and interests.

The Consultative Parties thus face a stalemate in designing a mineral resource regime. Their negotiations on these matters can only be fruitless, since the only acceptable solution is not theirs to implement.

\section{Proposal: An International Regime to Govern Antarctica as a World Common Space}

This Note has argued that common rights have evolved in Antarctica through the practice of states and persons from the colonial era to the present. Historical conditions and developments-Antarctica's

\& H. TAUBENFELD, supra note 21, at 11-49 (cataloguing failures of condominia around world, with rivalry among co-owners most common cause of failure); Note, supra note 1 , at 400-01 (no exclusive resource rights are vested in Consultative Parties, and condominium would violate provisions of Antarctic Treaty barring enlargement of claims).

188. See Wulf Interview, supra note 40 ("Some sort of joint venture system among the Consultative Parties is the most probable outcome at this point. This would have elements of a de facto condominium, not proclaimed formally."); cf. Hambro, supra note 100, at 224 (increased collaboration among Treaty Parties in regulating resources could lead to de facto condominium).

189. See Wulf Interview, supra note 40 ("The nonclaimant view is that free access should be guaranteed to all, for all purposes, but the claimant states see free access as a challenge to their claims. Some of these states support free access only for scientific, not for resource purposes.")

190. See Sellin Interview, supra note 3 ("One way that interests of the rest of the world" could be "taken into account" is through "revenue sharing."); Wulf Interview, supra note 40 ("Nearly all Consultative Parties support some form of plan to share beneficial interests with non-Consultative Parties.")

191. See Wulf Interview, supra note 40 ("There is some support for allowing a limited decisionmaking role for non-Consultative Parties in the regime once it is established, though it may be politically unrealistic to expect the Consultative Parties to agree to participation by other states in all facets of decisionmaking.") 
virtual inaccessibility until recent times, its isolation from struggles among the major powers, and now its emergence as a region of value at a time of rapid evolution of international institutions-have kept Antarctica free from division among exclusive interests. But events have outpaced the evolution of institutions in Antarctica. The Antarctic Treaty regime affirms Antarctica's special international status but is not well suited to resolve current issues of resource allocation and development. Resource plans promoted by the exclusive group of Treaty Consultative Parties jeopardize the interests of other states in Antarctica and contradict the principles of common right implicit within the Treaty itself.

A new form of administration is needed to take account of Antarctica's growing importance in world affairs and to represent the universal interests at stake in Antarctic policymaking. The expectation is building that this new administration for Antarctica must be fully international. Expressions of support for international administration have come from explorers, ${ }^{192}$ scientists, ${ }^{193}$ leaders and representatives of governments, ${ }^{104}$ legal advisers and scholars, ${ }^{195}$ environmentalists, ${ }^{106}$ public interest groups, ${ }^{197}$ and international civil

192. See, e.g., W. Sullivan, supra note 31, at 234 n.3 (Admiral Byrd promoting dedication of continent to "the ideal of brotherhood among peoples" by dropping flags of all members of United Nations at South Pole in 1947); Gould, supra note 39, at 25-26 (Commander Maury in 1861).

193. See, e.g., Zeller, Saunders \& Angino, supra note 5, at 8 (atomic scientists term Antarctica "land territory on earth" closest to being considered "truly international"); N.Y. Times, May 24, 1967, at 13, col. 1 (scientist calls for international park).

194. Sec, e.g., Conference on ANTARCTica, supra note 14, at 22 (representative of Soviet Union proposes international regime for Antarctica); note 29 supra (British Prime Minister in 1958 and British representative to Treaty Conference in 1959); cf. 19 Dep't STATE Bull. 301 (1948) (United States proposes "some form of internationalization" for Antarctica).

195. Legal scholars have been the most active in proposing a common-space type regime for Antarctica, beginning as early as 1934, see Reeves, supra note 29, at 119 (Antarctica is "international in fact" and should be so identified by "general agreement"), and continuing up to the 1959 Antarctic Treaty Conference, see, e.g., C. JENks, THE Common Law of Mankind 377 (1958) (proposing international resource regime); Sullivan, supra note 70, at 166 (international solution appropriate because Antarctica is uninhabited and "belongs to all mankind"). Following the Treaty Conference, scholars criticized the Parties' failure to adopt a more fully international solution. See, e.g., Taubenfeld, supra note 21, at 297 (favoring more "secure international" status for Antarctica). For more recent legal commentary, sce J. KISH, supra note $4 \mathrm{I}$, at 80 ("International jurisprudence recognizes the international status" of Antarctica.); N.Y. Times, Dec. 25,1976 , at 12, col. 3 (international law professor proposes "International Antarctic Authority" to "settle claims, protect the environment," and distribute resource wealth equitably).

196. See, e.g., N.Y. Times, May 24, 1967, at 13, col. 1 (former president of National Audubon Society proposes internationalization to protect environment); id., Apr. 26, 1975, at 27, col. 1 (400 delegates to international conference urge world park).

197. For early proposals for international authority in Antarctica by the Women's International League for Peace and Freedom, see U.N. Doc. T/PET/GENERAL 15, Oct. 4, 1947; U.N. Doc. T/PET/GENERAL 16, Oct. 4, 1947 (petitions to newly formed United Nations Trustceship Council). See also N.Y. Times, Jan. 12, 1958, at 37, col. 4 (Japanese 
servants. ${ }^{198}$ This support has been greatly strengthened by the emergence of new states in Latin America, Asia, and Africa as a political force, and by the advocacy of the leaders of these states of equitable concepts that are directly applicable to Antarctica. ${ }^{199}$ Covert negotiations by Consultative Parties no longer escape the notice of these states, and exclusive schemes of resource appropriation will arouse from them harsh cries of objection. ${ }^{200}$

The identification of Antarctica as a site for international administration is strengthened by similar characterizations of the seas ${ }^{201}$ and outer space. ${ }^{202}$ Like Antarctica, these other spaces for differing lengths

newspaper urges United Nations control over Antarctica as the "last ownerless, peaceful continent" ").

198. See, e.g., N.Y. Times, Aug. 29, 1975, at 28, col. 2 (executive director of the United Nations Environment Program calls for international control).

199. See p. 825 \& note 98 supra (equitable sharing of wealth and resources); p. $856 \&$ note 250 infra (special rights and preferential treatment for developing countries).

200. A common world interest in Antarctica was asserted by India, a leader of developing countries, as early as 1956 . India requested that the United Nations General Assembly consider "The Question of Antarctica," U.N. Doc. A/3118 (1956), since the "size" and "international importance" of Antarctica and "growing [world] interest" made it "appropriate and timely for all nations to agree and to affirm that the area will be utilized entirely ... for the general welfare." Id. addendum 2. In 1958, shortly before the Antarctic Treaty Conference, India reintroduced its United Nations proposal on the ground that Antarctic "mineral wealth" and sea resources are of "practical significance to the welfare and progress of all nations," and any treaty action should "only be taken by the world community as a whole." U.N. Doc. A/3852, at 2-3 (1958). The paucity of similar assertions by developing nations during the $1960 \mathrm{~s}$, when resource values of Antarctica were little known, does not suggest acquiescence or consent by those nations to permanent rule of Antarctica by exclusive interests. See 1 D. O'Connell, supra note 47, at 490 ("Absence of protest is ... a very relative concept in proof of title, since it is only when a State becomes interested that it has any motive for protest."); Note, supra note 1, at 403 (international "acquiescence" to Antarctic Treaty regime has not "solidified" any sovereign claims). More recently, however, representatives of Sri Lanka have argued before various councils of the United Nations that Antarctic mineral issues should be the subject of international negotiation. See U.N. Doc. E/AC.24/SR.563, at 72-73 (1975) (exploitation of Antarctica's "living and mineral resources" of "importance ... for the world economy"); U.N. Doc. A/PV.2380, at 13-16 (1975) ("new initiative" needed by "international community" to apply to Antarctica "widely accepted" concepts of economic cooperation and equitable sharing of resources). See also Mitchell, Antarctica: A Special Case?, 73 New ScIENTIST 64, 66 (1977) (foreseeing Third World reaction against control of Antarctica by "small band of countries"); Mitchell, Resources in Anlarctica: Potential for Conflict, Marine Poz'r, April 1977, at 91, 100 ("only a matter of time before a coordinated protest movement gets under way").

201. Various commentators have analogized Antarctica to the seas. See Goldblat, supra note 124, at 287 (Antarctic resources should be exploited "in the interest of mankind-in the same way as the sea-bed and ocean floor ... are planned to be used"); Hargrove, supra note 37, at 1 (there exists "a close analogy between the problems of lawmaking for Antarctic resources and ... for ocean resources").

202. Outer space also has often been analogized to Antarctica. See, e.g., Sullivan, supra note 70, at 166 (international regime for Antarctica could be "rehearsal" for the moon); Note, supra note 68, at 174 n.5 (Antarctic experience useful as model for "development of amicable relations in outer space"). Other commentators have drawn outer space into broad analogy with both Antarctica and the seas. See Commission to Study the Organiza- 
of time have been zones of universally free and common access. ${ }^{203}$ And like early explorers of Antarctica, navigators of the sea and space-craft exploring the moon and distant planets have not been precursors of extensions into those spaces of national sovereign control. ${ }^{201}$ These results follow from the conditions that distinguish these spaces from most land spaces on earth. The deep seabed, outer space, and Antarctica are all unsuitable as sites for extended human habitation, and the principal benefits to be gained from each space have not historically required exclusive control. The inner regions of space, as well as the seas and Antarctica, play a highly sensitive role within the earth's ecological system. And each space has emerged as a site of critical value in the post-colonial era, when concepts of international law no longer allow new spaces and territories to be seized by the first to arrive, the nearest in location, or the most powerful. ${ }^{205}$

With minor variations, the concept of the "common heritage of mankind" 206 has already been applied to the seas ${ }^{207}$ and to outer

TION OF PEACE, supra note 110, at 207 (outer space, high seas, seabed and Antarctica compared as examples of "open territory," subject to no recognized national claims); Hanevold, supra note 123, at 106 (outer space, seabed, and Antarctica have "common characteristics" that make them similar in legal and political sense; since they "belong" to no state, questions of sovereignty over them are unresolved, and all are undergoing "rapid development"); Hargrove, supra note 37, at 2 (outer space, oceans, and Antarctica constitute "trilogy of the earth's remaining common spaces").

203. See note 215 infra (principle of common access applicable to each area).

204. See, e.g., Composite Text, supra note 52, art. 87 (all forms of navigation, overflight, and other activities allowed on high seas, but "[t] $]$ he high seas are open to all states"); Outer Space Treaty, supra note 74, art. V (states "shall regard astronauts as envoys of mankind in outer space").

205. See p. 824 \& note 91 supra (discovery, contiguity, and occupation are colonial concepts); pp. 825-26 \& notes 96.99 supra (colonial theories of control now rejected in favor of other principles).

206. "Common heritage" is a "new concept in international law" with "emerging" content. Introduction to Part Three: The Emerging Ocean Regime, in PaceM IN MARIBUS, supra note 153 , at 161 . It has been suggested that the concept has three characteristics: "absence of [national] property," international "management of all uses," and "sharing of benefits." Id. at 162 (quoting statement of Ambassador Pardo in 1970); cf. Djordjevic, The Social Property of Mankind, in id. at 166 (advocating international application of unconventional Yugoslavian concept of total absence of property rights). Concepts of common heritage reflect the perceived trend in international law towards a substitution of inclusive for exclusive policies and the need to hold "the great bulk of space resources ... open for ... enjoyment by all, and not made subject to exclusive acquisition." McDougal, Lasswell, Vlasic \& Smith, supra note 51, at 636 .

207. See Composite Text, supra note 52, art. 136 (seabed, ocean floor, and ocean floor subsoil beyond limits of national jurisdiction are "common heritage of mankind"); Declaration of Principles Governing the Sea-Bed and the Ocean Floor, and the Subsoil Thereof, beyond the Limits of National Jurisdiction, G.A. Res. 2749, 25 U.N. GAOR, Supp. (No. 28) If 1 , at 24, U.N. Doc. A/8028 (1971) (resources of seabed and ocean floor are part of common heritage) [hereinafter cited as Sea-Bed Declaration]; cf. M. McDoucal \& W. Burke, The Public Order of the Oceans 562-63 (1962) ("international law of the sea" has served to protect "common interests of all states" in region "long regarded as the common patrimony of all mankind"). 
space, ${ }^{208}$ and has identified each space as a site of rights shared by all people of the world in common and subject only to international forms of regulation. Because Antarctica is closely analogous in history and value to these other spaces, negotiations under way at the Third United Nations Conference on the Law of the Sea ${ }^{200}$ and international agreements already in effect with respect to uses and protection of the moon and outer space ${ }^{210}$ set important precedents for the international accords needed also for Antarctica, and suggest that similar commonheritage concepts should be applied to Antarctica. ${ }^{211}$

This Note has defined a world common space as a space that is, or may become, of value to mankind generally and for which there has developed a practice or general expectation of common access, use, or control. ${ }^{212}$ Antarctica conforms to this definition. Antarctica therefore must be governed by the principles of an international "law of common spaces," and an international "common-space" regime must be established. Such a regime can achieve an equitable, acceptable, and workable accommodation of all interests at stake.

\section{A. Principles of the Law of Common Spaces Applicable to Antarctica}

The principles of common-space law applicable to Antarctica arise from the history of practice and agreement in Antarctica and in the other world common spaces. Since by historical processes Antarctica has already come to be identified as a common space, no proclamations or conventions are needed in order to bring these rights and

208. See Outer Space Treaty, supra note 74, art. I ("The exploration and use of outer space ... shall be carried out for the benefit and in the interests of all countries ... and shall be the province of all mankind."); Bleicher, An Overview of International Environmental Regulation, 2 EcoLoGy L.Q. 1, 66 (1972) ("the world community has increasingly recognized the shared resource character of the atmosphere").

209. See generally Composite Text, supra note 52 (latest draft of Conference negotiations).

210. See, e.g., Outer Space Treaty, supra note 74.

211. See J. Kish, supra note 41, at 1, 197-98 (legal status of seas, polar regions, and outer space is already largely uniform under international law, but new international organizations are needed for each space in order to bar exclusive claims, protect common interest, and regulate strategic use); Sollie, supra note 34 , at 128 ("highly desirable to have identical rules for all" new territories).

212. See p. 807 supra. Cf. Ostreng \& Skagestad, The Challenge of New TerritoriesAn Introduction, 9 CoOperation \& Conflict 53, 54 (1974) (“[N]ew territories" are "areas which (a) have not previously been subject to the internationally recognized sovereignty of any state or placed under the authority of any international organizalion, and which (b) are becoming the object of activities which create the need for the regulating and control of what occurs in the area."); id. at $\mathbf{5 4}$ (common characteristic of new territory is that there is no pre-existing "international apparatus capable of dealing with the problems of" the territory). 
obligations into immediate effect. These common-space principles, founded on historical experience throughout Antarctica and consistent generally with precedent in other common spaces, apply to the entire Antarctic Treaty area regardless of any future boundary delimitation or division of responsibilities between regimes established for Antarctica and for the world's deep seabed. ${ }^{213}$

\section{Common Sovereignty Over Space}

The land and adjoining ice-shelves, seabed, and waters of Antarctica are a common heritage of mankind and cannot be apportioned into sectors or other exclusive divisions. No national or multinational territorial claims in Antarctica are valid or can serve as the basis for any new Antarctic regime. ${ }^{214}$

213. Though the Antarctic Treaty applies to all regions south of $60^{\circ}$ South Latitude, "including all ice shelves," the Treaty purports not to "prejudice" or "affect . . . in any way" the rights of states on the "high scas" within that area. Antarctic Treaty art. VI. The extent of the "high seas," howerer, is not defined, thus throwing into question the applicability of the Antarctic Treaty to the offshore continental shelf, seabed, and many ice formations lying either within or over the Antarctic "high scas." Many commentators have assumed that the legal status of these spaces must conform to the legal status of the Antarctic continent. See, e.g., Jones, Whose Oil Resources? The Question of Antarctic Sovercignly, 61 Geography 167, 167 (1976) (offshore oil rights hinge on land rights); Lundquist, supra note 5 , at 40 (unresolved legal status of Antarctic continent casts "cloud" over entitlements to icebergs). Others have argued that in the absence of recognized national sovereignty on the continent, the continent is not a "state" and can have no territorial sea. Therefore, all surrounding spaces must be high seas. See, e.g., J. KISH, supra note 41, at 33 (Antarctic scas and islands not within any territorial sea); Mouton, supra note 15, at 196-97 (no territorial sea). Searching also for a body of law applicable to Antarctic ice, commentators have quibbled about whether the ice-shelves attached to the continent of Antarctica, the seasonal pack-ice, and cven the continent itself, which is largely covered with ice and lies mostly below sea-level, see Bernhardt, supra note 48, at 298,299 \& $\mathrm{n} .9$, should be characterized as "land" or "sea" and thus be subject to "land" or "sea" law. See, e.g., id. at 299-310; Richardson, supra note 16, at 39-40. However, the physical properties of land, water, and ice are not relevant considerations under commonspace law. All spaces that satisfy the definitional requirements of a common space, see p. 807 supra, are subject to common-space principles. Although the relationship between future seabed and Antarctic regimes will be subject to negotiation, both regimes should be governed by similar common-space principles. Furthermore, all spaces lying within the Antarctic Treaty area are subject to certain principles arising uniquely out of Antarctic practice and agreement, such as the principle of peaceful use. See pp. 810, 829, 833 and notes $23,113 \& 137$ supra, p. 852 \& notes 229-31 infra. Therefore all spaces of the Antarctic Treaty area, including the seabed, continental shelf, land, water, and all ice formations are subject at present and should remain subject in the future to all principles of common-space law outlined in this Note, regardless of the nature of the common-space regime that assumes the responsibility for governing each of those spaces.

214. See J. KISH, supra note 41 , at 52 (prohibition against territorial sovereignty "basic rule" of "international spaces"). For sea-law analogy, sce Composite Text, supra note 52, art. 89 (no part of high seas subject to state sovereignty); id. art. 137 (no state sovereignty over seabed or its resources). For outer-space law, see Draft Treaty Concerning the Moon art. VIII(1), U.N. Doc. A/8391 (1971) (surface and subsoil of moon not subject to property claims) [hereinafter cited as Draft Moon Treaty]; Outer Space Treaty, supra note 74, art. II (outer spacc and celestial bodies not subject to national sovereignty or: appropriation through use, occupation, or other means). 


\section{Common Rights of Access}

Since Antarctica is held in common, access to all regions of Antarctica by all parties for purposes consistent with common-space law must be unhindered, subject only to nondiscriminatory guidelines promulgated by a common-space regime (for example, to protect the Antarctic environment or to regulate or bar the exploitation of resources). The Treaty Consultative Parties have no authority to bar other parties from gaining free access to Antarctica for purposes consistent with common-space law. ${ }^{215}$

\section{Common Rights to Resources}

Land, water, and ice resources of Antarctica are held in common.216 No claims of exclusive right to these resources, no licenses or permits issued by exclusive parties to private companies, ${ }^{21 \tau}$ and no regulations facilitating or barring development ${ }^{218}$ are legally binding on the world community unless promulgated by a common-space regime. Exploitation of nonrenewable resources is barred absolutely until such a regime has assumed authority. ${ }^{219}$ Renewable resources, however, may be used subject to certain conditions and limitations.220

\section{Common Rights in Decisionmaking}

The process of making all decisions concerning Antarctica, including the initial structuring of the Antarctic regime and its eventual

215. For discussion of early exercise of rights of access in Antarctica, see pp. 808-11 \& notes 12-26 supra. These rights were affirmed by the Antarctic Treaty. See p. 831 \& notes 123-24 supra. For analogous sea and outer space law, see J. Kish, supra note 41, at 54-56 (free navigation of high seas upheld from ancient times to present); Draft Moon Treaty, supra note 214, art. V(1), (2) (right to move anywhere on surface or in subsoil of moon or in circumlunar space); Outer Space Treaty, supra note 74, art. I (free exploration of outer space and access to all areas of celestial bodies).

216. See J. Kish, supra note 41, at 4 (the "international regime of Antarctic lands and ice shelves extends to their subsoil, down to the centre of the earth"). For sea and outer space law, see Composite Text, supra note 52, art. 137(2) (all rights to resources of seabed "are vested in mankind as a whole" and "are not subject to alienation"); Draft Moon Treaty, supra note 214, art. VIII(2) ("Portions of the surface or subsoil of the Moon" not to be "object of concession, exchange, transfer, sale or purchase, lease, hire, gift or any other arrangements or transactions with or without compensation.")

217. Cf. 14 International Legal. Materials 66 (1975) (claim of exclusive right by Deepsea Ventures, Inc., private United States company, to mine seabed deposits of manganese nodules under broad regions of Pacific Ocean, not recognized by United States).

218. See p. 837 \& note 151 supra (lack of authority in Consultative Parties to bind other states to resource regulations).

219. Cf. Composite Text, supra note 52, art. $137(2)$ (seabed minerals alienable only in accordance with rules of Third United Nations Law of the Sea Convention).

220. See p. 838 \& notes $154-56$ supta (stipulations of nondiscriminatory access, care for environment, and nondepletion of resource supplies). 
administration, must allow full participation by all nations. ${ }^{221}$ Removal of conditions to gaining Antarctic Treaty Consultative status cannot satisfy the requirement of participation in all stages of structuring and administering an Antarctic regime. 222

\section{Common Rights and Obligations of Environmental Protection}

To protect Antarctica's environmental, scenic, and scientific values ${ }^{223}$ and its potential for designation as an international environmental park, ${ }^{224}$ no party prior to the establishment of a common-space regime may take any action that involves a foreseeable risk of harm to the purity and natural condition of Antarctica's air, ice, land, or water. ${ }^{225}$ Several techniques of mineral exploration and all mineral exploitation activities in Antarctica, as well as over-exploitation of Antarctica's renewable resources, are therefore temporarily barred by environmental principles ${ }^{226}$ as well as by the common-rights principle barring depletion of resources belonging to all. ${ }^{227}$ In balancing environmental and resource needs, even an Antarctic common-space regime must respect the baseline principle that all common spaces, regardless of economic value, must be free from unreasonable environmental abuse. 228

221. See pp. 833-37 \& notes 139-48 supra (existing Treaty structure weakened by exclusivity in decisionmaking); cf. Composite Text, supra note 52, art. 154(2) (all states to be "ipso facto members" of International Sea-Bed Authority); id. art. 155(2) (principle of "sovereign equality" of all Sea-Bed Authority members).

222. See pp. 853-54 \& notes 240-43 infra (need for international conference or other fully international initiative to establish Antarctic common-space regime).

223. See p. 827 \& notes 106-08 supra.

224. See p. 839 \& note 160 supra.

225. Antarctica's environmental properties are a valuable and nonrenewable resource comparable to other nonrenewable resources. See p. 850 supra (only common-space regime has authority to regulate use of Antarctica's nonrenewable resources).

226. See p. 827 \& note 109 supra (existence of risks to environment involved in all forms of Antarctic resources development); p. 839 and notes 161 \& 162 supra (environmental hazards of mineral activities, whether regulated or unregulated).

227. See p. 850 \& notes 216-19 supra.

228. See Skagestad \& Traavik, supra note 85, at 94 ("special circumstances" of present lack of contamination, vulnerability to ecological disturbance, increased economic activity, and location beyond national boundaries create need for international cooperation to protect environment of all "new territories," including Antarctica); cf. Composite Text, supra note 52, art. 195(1) (states to take "all necessary measures . . . to prevent, reduce and control pollution of the marine environment from any source," using "best practicable means at their disposal"); Draft Moon Treaty, supra note 214, art. IV (exploring parties must avoid contamination and disruption of lunar environment). See generally p. 827 \& note 105 supra (general obligation of world environmental protection). 


\section{Rights and Obligations of Peaceful Use}

In accord with longstanding Antarctic agreement and practice, ${ }^{229}$ historically unique among common spaces, ${ }^{230}$ no forms of military armaments or military activity may be introduced into Antarctica. ${ }^{231}$ A properly constituted common-space regime, however, may ensure the enforcement of its rules and principles by operating an international security patrol..$^{232}$

\section{Freedom of Scientific Research and Obligations of Information-Sharing}

Scientific research not in violation of environmental or other common-space rules must remain free and unhindered. ${ }^{233}$ Since scientific knowledge in Antarctica has important economic and environmental value, ${ }^{234}$ and since certain information-sharing practices are already well established in Antarctica, ${ }^{235}$ states and persons should have the right to know of and to gain access to all results and reports of Antarctic scientific investigations conducted by other states and persons, including all information pertaining to the location and value of Ant-

229. See pp. 810, 829, 833 and notes 23, 113 \& 137 supra; Eighth Consultative Report, supra note 5, Rec. VIII-8 at 222 (reaffirming "the interest of all mankind that Antarctica shall continue forever to be used exclusively for peaceful purposes").

230. See J. KisH, supra note 41 , at 61 ("The freedom of the high seas comprises freedom of navigation and ... of military activities ...."); id. at 88 (freedom of "conventional" military activities in outer space). But cf. id. at 183 (United Nations Charter art. 2(4) bars "threat or use of force" against any state in any space, including high seas, polar regions, and outer space, but permits "self-defense"). New international agreements pertaining to the sea and outer space invoke a broad obligation of peaceful use similar to that applied earlier in Antarctica. See, e.g., Composite Text, supra note 52, arts. 88 \& 141 (high seas and seabed reserved for peaceful purposes); Outer Space Treaty, supra note 74, art. IV (moon and other celestial bodies to be used exclusively for peaceful purposes, no weapons of "mass destruction" in outer space).

231. See C. JENks, supra note 195, at 380 ("[C]ontinued demilitarisation of Antarctica" is "essential element in any . . . international régime.")

232. See, e.g., Commission to Study The Organization of Peace, supra note 110, at 216 (proposing "small police force or inspection force to patrol the continent"); Mouton, supra note 15, at 272 (aerial inspection of Antarctica by United Nations police force).

233. See pp. 810-11 and notes 25 \& 108 supra (customary practice of unhindered scientific research); Antarctic Treaty art. II (freedom of scientific investigation to continue); cf. Composite Text, supra note 52, arts. 87(1)(f), 239, 241(a) (freedoms of high seas include freedom of scientific research); Outer Space Treaty, supra note 74, art. I ("freedom of scientific investigation in outer space").

234. See p. 835 \& note 145 supra.

235. See Taubenfeld, supra note 21, at 268 (I.G.Y. agreement that "scientific knowledge gained was to be shared by all nations"); Antarctic Treaty arts. III(l)(a), (c) \& VII (providing for exchange of information about scientific programs and observations, and for Consultative Party inspections). 
arctic resources and the techniques and environmental risks of resource use. ${ }^{238}$

\section{B. Toward an Antarctic Common-Space Regime}

To coordinate international efforts and to enforce the principles of common rights in Antarctica, an international "common-space regime" should be established. The regime, which may be modeled after plans proposed for the administration of resources of the deep seabed, ${ }^{237}$ should be structured in accord with all the principles of common spaces; for example, a regime that provides for common access to Antarctica but allows first come, first served appropriation of Antarctic minerals and vests sovereign rights or special administrative powers in one or several states would not constitute a legitimate common-space regime. ${ }^{238}$

To be consistent with the principle of common rights in decisionmaking, ${ }^{239}$ the proposed regime must be established through fully international deliberations. As a world body, the United Nations could intervene directly either to establish a trusteeship ${ }^{240}$ or to exercise

236. See Notc, The Polar Regions and the Law of the Sea, 8 CASE W. REs. J. INT'L L. 204, 216 (1976) (benefits of scientific information gained by any nation in Antarctica should be available to all). For proposed sea law, see Compositc Text, supra note 52, arts. $143(2)(c), 245(1)$ (results of marine scientific research to be published and disseminated effectively through international channels); $i d$. arts. 144, 267 (promoting transfer to developing countries of marine and seabed scientific knowledge and technology). For outer space law, see Outer Space Treaty, supra note 74, arts. X, XI (observation of other states' space flights, and dissemination of information concerning "nature, conduct, locations and results" of space activities). See generally Künzli, Science as the Social Property of Mankind, in Pacem IN MARIBUs, supra note 153, at 207 (proposing that all scientific knowledge should be public knowledge).

237. See Composite Text, supra note 52, arts. 133-192; cf. Hargrove, supra note 37, at 16 (feasible to establish "a regime for Antarctica like that which may be emerging for the deep seabed"); Sollie, supra note 34 , at 128,142 (seabed solutions may set "an example and precedent for a similar approach to the problems of Antarctica").

238. The "Spitsbergen plan" is therefore not applicable to Antarctica. By treaty among nine states in 1920, full sovereignty over a nearly uninhabited but resource-rich archipelago in the Arctic region was granted to one of the Treaty Party states, but the islands were left open for access and for all forms of economic use by other states. For general discussion of the Spitsbergen plan, see G. HAckworth, supra note 16, at 465-68; P. JEssup \& H. TAubenfeld, supra note 21 , at $34-39,181$. Similarity has been noted between the Spitsbergen plan and condominium proposals for Antarctica. See, e.g., Rose, supra note 151, at 25-26. For criticisms of the plan's proposed application to Antarctica, see Hambro, supra note 100, at 224 (Spitsbergen solution "out of the question"; analogy fails because national sovereignty was recognized in Spitsbergen, but has not been in Antarctica); Sollie, supra note 2, at 81 (Spitsbergen example useful only as precedent for limiting national sovereignty over new territories, and as transitional model to terra communis).

239. See pp. 850-51 supra.

240. The United Nations "International Trusteeship System," U.N. CharTer arts. 7585, provides a mechanism for the exercise of United Nations authority over "the administration and supervision of such territories as may be placed thereunder by subsequent individual agreements," $i d$. art. 75. Just two years after the United Nations was 
some other form of administrative control ${ }^{241}$ over Antarctica. The United Nations could also convene an international conference ${ }^{242}$ leading to the establishment of an independent Antarctic regime. A seabed resource regime, if instituted in basic accord with commonspace principles, by agreement of its parties could also extend jurisdiction over Antarctica. ${ }^{243}$ The Antarctic Treaty, unless terminated

established, obscrvers called for United Nations trusteeship control over Antarctica. See note 197 supra (1947 petition by Women's International League for Peace and Freedom). Similar proposals were made during the years just prior and subsequent to the Antarctic Treaty Conference in 1959. See Ratification Hearings, supra note 37 , at 65 (Sen. Morse) (United Nations trusteeship over Antarctica "for the next 50, 75, 100 years"); Hayton, supra note 32, at 607 (likelihood of "exceptional, noninhabited trusteeship" for Antarctica); The Times (London), Jan. 25, 1956, at 8, col. 6 (New Zealand Labour Party leader) (U.N. trusteeship over Antarctica so citizens of all nations to have "equal privileges"). For a more recent expression of support, see Hambro, supra note 100, at 225 (Antarctic trusteeship "perfectly possible under Article 81 of the Charter ....") See U.N. CHARTER art. 81 ("[T]he administering authority [for a trusteeship agreement] . . may be one or more states or the [United Nations] Organization itself.")

241. Many observers have called for exercise of United Nations authority over Antarctica outside the trusteeship system. See Commission to Study the Organization of PEACE, supra note 110 , at 215 ("direct United Nations administration of the whole continent"); P. JESSUP \& H. TAUBENFELD, supra note 21 , at 180 ("surrender of national claims" to a United Nations body or "some new entity"). It has been proposed specifically that a specialized agency of the United Nations General Assembly would be the most suitable mechanism, Goldie, supra note 15 , at 25 , and that a separate United Nations "Neutral Territories Council" for Antarctica could be established, Hayton, supra note 29, at 765 . United Nations administration has been identified recently as the "ideal solution." Rose, supra note 151, at 25. A United Nations role in Antarctica could serve to adrance the interests of developing countries. See generally New Economic Order, supra note 93, $\mathbb{f} 6$ (promoting United Nations as "universal organization ... capable of dealing with problems of international economic co-operation . . . and ensuring equally the interests of all countries"); R. ANAND, supra note 91, at 73-74 (United Nations provides new influence for states that are individually "weak and ineffective"). A United Nations role in developing a new and equitable form of international organization for Antarctica could also be in the interest of morc developed states, such as the United States. See pp. 857-58 \& note 252 infra.

242. An international conference is an appropriate means of establishing a new international institution such as a common-space regime. It has been proposed that a "plenipotentiary conference" convened either under United Nations auspices or "otherwise" to develop an international resource regime for Antarctica should involve the participation of a "substantial number of states other than the original Treaty partics" and would be a useful mechanism for "marshalling political pressure" to counter expected opposition of Antarctic claimant states. Hargrove, supra note 37, at 15-16; cf. Sea-Bed Declaration, supra note 207 , $\llbracket 9$ (seabed regime to be established by "international treaty of a universal character, generally agreed upon"); note 243 infra (possible role of Third United Nations Conference on Law of the Sea).

243. See Note, supra note 1 , at 402 (proposing delegation of authority over Antarctic offshore regions to agency such as "proposed United Nations Seabed Authority"). The issue of Antarctica has not yet been brought up for discussion before the Third United Nations Conference on the Law of the Sea. Sri Lanka has proposed such discussion but some delegations fear that the Antarctic issue could hinder the reaching of agreement on law of the sea accords as a whole. See, e.g., Moore Interview, supra note 183 ("The United States is opposed to the entry of Antarctica in law of the sea negotiations, because of concern that introduction of an additional complex issue could further burden already difficult negotiations.") Failure of the Law of the Sea Conference to consider Antarctica should not, however, prevent an appropriately constituted seabed regime from exercising authority over Antarctica in the future. 
or abrogated, will continue to bind Party states. But the focus of world attention and concern must shift away from the Treaty structure to the task of building the new common-space regime.

Generally, there must be devised for the new regime a practical structure for governance, formulas and programs for development and distribution of benefits, and rules for enforcement.

Formal decisionmaking responsibility should rest in a legislative body. ${ }^{244}$ To gain acceptance from the developed world, criteria for participation in at least one decisionmaking council of the new Antarctic regime should give regard to a state's degree of industrial development. On the other hand, ample representation must also be provided to less-developed nations to guarantee a hearing for their interests. Thus, a bicameral legislative system similar to that of the United Nations should be instituted to balance the needs of the more powerful industrial states with those of the more numerous, less-developed ones. ${ }^{245}$

Experience under the Antarctic Treaty demonstrates the frailty of a multinational organization with no executive structure. ${ }^{246}$ For the sustained and complicated task of coordinating international regulatory efforts in Antarctica, a strong executive body with a staff of international civil servants will be needed to administer the regime. ${ }^{247}$

244. Cf. Composite Text, supra note 52, art. 158(1), (2) (Assembly of Sea-Bed Authority to be "supreme organ," with power to establish general policies and to elect Council members and Secretary-General).

245. An organizational form that gives greater weight than the United Nations to the votes of developing countries is contemplated, in the current stage of negotiations, for the new Sea-Bed Authority. The Sea-Bed Assembly, see note 244 supra, is to consist of all members of the Authority, Composite Text, supra note 52, art. 157(1). Each Assembly member is to have one vote, $i d$. art. $157(5)$, with questions of "substance" decided by twothirds majority, id. art. 157(6). However, a "Council" is established above the Assembly, $i d$. art. 160, with a more limited membership of parties selected according to a complicated formula of geographic, economic, and other factors. Id. art. 159(1), (2). Though designated an "executive" organ, id. art. 160(1), the Council is afforded such extensive authority, see id. art. 160(2), that it could be expected to counterbalance the authority of the one-state, one-vote Assembly. Such "weighted voting" may be necessary in at least one decisionmaking council of an international organization. See, e.g., P. Jessup \& H. TAubenfeLd, supra note 21, at 127-28, 182; Note, supra note 236, at 217. The system of representation for the Antarctic regime, however, need not follow precisely the seabed or any other particular model. See Introduction to Part Three: The Emerging Ocean Regime, in PacEM iN MARIBus, supra note 153, at 163-64 (common-heritage concept requires "new forms of decision-making, based on new forms of 'representation' "; neither a "one-state-one-vote" nor an exclusively population-based system will be appropriate).

246. See, e.g., Hayton, supra note 120 , at 368 (international bureau with "central staff, a budget, a headquarters, and field offices "down on the ice" " needed for Antarctica); $c f$. Skolnikoff, National and International Organization for the Seas, in UsES OF THE SEAS 98, 102 (E. Gullion ed. 1968) (analysts note that executive action promotes efficiency and reduces bureaucracy in international organizations).

247. Cf. BIOMASS, supra note 2, at 66 (scientific planning group for new Southern Ocean living resources regime to require "semi-permanent secretariat" for "effective 
The legislature of the regime should set guidelines and programs to determine the appropriate balance between environmental protection and resource use. If Antarctica is not to be preserved in its entirety as an environmental park, studies should be commissioned to determine useful rates and means of resource development; the regime should then lease out resource rights to developers. ${ }^{248}$ Consortia of investors from less-developed countries may be provided with special technical and administrative assistance needed for full participation in development. ${ }^{249}$ Also, to promote a more equitable distribution of world income and in accord with evolving concepts of international law, the proceeds from resource development should be shared according to a formula that gives special benefit to developing countries. ${ }^{250}$ No resource use should be allowed that does not have high likelihood of bringing beneficial return to the Antarctic regime as a whole and that does not further common interests.

Finally, the international regime must protect Antarctica's status as a world common space. The regime should guarantee freedom of scientific research and information-sharing, freedom of travel, and noninterference with the common rights of others. To enforce these

functioning" once large-scale exploitation begins); Composite Text, supra note 52, art. 165(I) (providing for Secretary-General and staff of Sea-Bed Secretariat); id. art. 167(1) (Secretariat officials to be international in character, not accountable to any individual member governments).

248. Developers will require exclusive rights to operate in designated areas. See C. JENKs, supra note 195, at 377 (proposing scheme of "licenses or concessions . . for the working of minerals" in Antarctica, under international authority); Note, supra note 1 , at 401-02 (companies exploring for offshore oil to need exclusive licenses; proposing scheme through United Nations); cf. Eckert, Exploitation of Deep Ocean Minerals: Regulatory Mechanism and United States Policy, 17 J.L. \& Econ. 143, 143-44 and nn.3 \& 4 (1974) (quoting Senate testimony of corporate executives on need for exclusive licensing); Composite Text, supra note 52, Annex II (providing for letting out of contracts for exploration and exploitation of seabed resources).

249. Cf. Composite Text, supra note 52 , art. 143(2)(b) (marine scientific programs to aid research capabilities of developing countries, also to train and foster employment of their personnel); $i d$. art 144 (promoting transfer of marine technology and scientific knowledge to developing countries).

250. See New Economic Order, supra note 93, $\{4(\mathrm{n})$ (new international economic order to respect principle of "[p]referential and non-reciprocal treatment for developing countries'); p. 825 \& note 98 supra (international obligation to aid developing countries). Special rights of developing countries are recognized throughout the current negotiating text of the Third United Nations Conference on the Law of the Sea, for example, in the "equitable sharing" of proceeds from development of the continental shelf beyond two hundred miles, Composite Text, supra note 52, art. 82(3), (4); in setting catch limits for fishing on high seas, $i d$. art. 119(1)(a); in the management by coastal states of economic zone living resources, $i d$. art. 61(3); in seabed development, $i d$. art. 148; and in allocating funds and services for marine pollution control, $i d$. art. 204. It is also stated specifically that the Sea-Bed Authority is to establish a system for the "equitable sharing" of resource benefits by giving special consideration to geographically disadvantaged, developing, and non-self-governing countries and peoples, $i d$. art. 151(9), and that all such special consideration is not "discrimination," $i d$. art. $150(2)(\mathrm{b})$. 
and other rules of common-space law, mechanisms such as economic sanctions and peacekeeping forces already employed by other international institutions may also be employed by the Antarctic regime. ${ }^{251}$

\section{Defense of the Common-Space Regime}

The proposed regime would reflect both the historical pattern of practice and agreement in Antarctica and contemporary principles of international law and equity. The regime would also displace the stalemated Treaty structure and facilitate environmental and resource planning. Thus the regime should be acceptable to the world community and should provide a workable solution to current Antarctic problems of resource planning and decisionmaking.

\section{Acceptability}

Despite predictable objections by claimant states and misgivings of other Treaty states, a common-space regime in Antarctica promises to become generally acceptable because the advantages to be gained outweigh risks of loss. Through the regime, Treaty states forsake only the unlikely possibility that non-Party states will eventually acquiesce in recognizing territorial claims and in allowing exclusive resource schemes to proceed. Treaty Parties gain, on the other hand, a peaceful reconciliation of conflicting economic interests; facilitation of complex and profitable forms of Antarctic activity through removal of serious practical obstacles, such as unclear jurisdictional boundaries and investment rights; an equitable distribution of benefits from resource development, thus promoting a more stable and prosperous world society; the opportunity to gain world support for protection of an important environmental reserve; and the indefinite separation of Antarctica from major power hostilities.

Particular nations will also benefit from the common-space regime. The United States can ensure the continued availability of Antarctica for scientific research and can lead the way toward the creation of a new and equitable international organization, in accord with its basic foreign policy concerns. ${ }^{252}$ New Zealand, Australia, Chile,

251. See C. Jenks, supra note 195, at 373 (no courts or police required for Antarctica, but perhaps "part-time justices of the peace" and "special constables" to enforce Antarctic regulations); cf. Composite Text, supra note 52, art. 151(4), (5) (Sea-Bed Authority to excrcise control as necessary to secure compliance with regulations). Mechanisms for the settlement of disputes may also be provided for law of the sea. See id. arts. 279-97; id. Annex V (Sea Tribunal).

252. Cf. Falk, Historical Tendencies, Modernizing and Revolutionary Nations, and the International Legal Order, \& How. L.J. 128, 141 \& n.25, 148 (1962) ("National pursuits of 
and Argentina, with no realistic expectation of enforcing their vast Antarctic claims, will be assured some role on the continent and also the continued presence of a peaceful regime in the Southern Hemisphere. Britain will be guaranteed a graceful exit from a longstanding feud with Chile and Argentina over overlapping claims, and both Britain and France will be relieved of the expense of maintaining remote Antarctic outposts of their diminishing colonial empires.

Other world states, with no prior investments at stake, stand only to gain from a regime that provides a vehicle for the implementation of collective interests. These states are not only certain to accept a common-space approach, but they may require it as a precondition to recognizing and cooperating with any regime that attempts to administer Antarctic resources.

\section{Workability}

Increasingly sophisticated forms of international cooperation in the areas of trade negotiation, commercial lawmaking, arbitration of disputes, development loanmaking, and communications suggest that the task of administering the Antarctic regime will not be impractical. The United Nations, despite its many failings, illustrates the feasibility of systems of international decisionmaking and administration far more complex than those required for Antarctica.

The important advantages to be gained from working cooperatively within the common-space regime will be apparent to the many states whose interests will be served and to all states with an interest in peaceful international relations, environmental protection, and orderly forms of economic development. Law of the sea negotiations, though difficult, and international agreements already in effect with regard to outer space reflect the widespread understanding that even complex forms of international administration stand a greater chance of functioning successfully in common spaces than secretive, exclusive schemes that meet with political objection.

power, wealth, and prestige no longer serve the deeper interests of the [United States and other large, rich nations] . ... The national interest of the United States is often served best by encouraging changes in the legal order that acknowledge new interests and demands of the modernizing... nations. We should want as many nations as possible to have a stake in the legal system as it operates ...."); Ratiner \& Wright, United States Ocean Mineral Resource Interests and the United Nations Conference on the Law of the Sea, 6 NAT. Resources LAw. 1, 18 (1973) (authors officials in U.S. Dep't of Interior; L. Ratiner a member of U.S. Delegation to U.N. Seabeds Committee; both expressing personal views) ("The creation of viable international institutions with world-wide participation ... furthers the possibility, of particular interest to countries like the United States, of ensuring a more stable and secure world order.") 


\section{Conclusion}

Institutional arrangements currently applicable to Antarctica are inadequate to deal with pressing new issues. A new form of international governance is needed to reflect the history and likely future of Antarctic activity and the wide range of interests at stake. Time has run out for the self-selecting society of Treaty Parties who purport to provide all law and authority for Antarctica; scores of new states have joined the international community since those Parties signed their compact in 1959, and a new balance of power has thrown the institutional and legal arrangements of that earlier day into disarray.

Antarctica in practice has never been and institutionally can no longer be isolated from world trends toward interdependence and sharing. The age of territorial exclusivity has passed its peak, and vast new spaces-the seas, outer space, and Antarctica-must now be subject only to the cooperative control of the world community. 